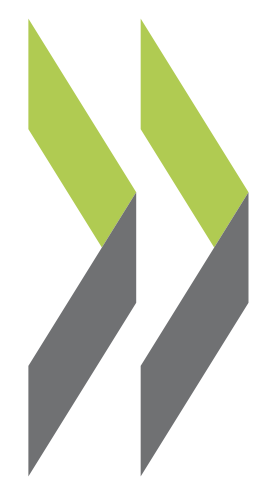

OECD Economics Department Working Papers No. 882 Predicting Peaks and Troughs in Real House Prices

Linda Rousová, Paul van den Noord 
Organisation de Coopération et de Développement Économiques

Organisation for Economic Co-operation and Development

13-Jul-2011

ECONOMICS DEPARTMENT

English - Or. English

PREDICTING PEAKS AND TROUGHS IN REAL HOUSE PRICES

ECONOMICS DEPARTMENT WORKING PAPER No. 882

By Linda Rousová and Paul van den Noord

All Economics Department Working Papers are available through OECD's internet web site at www.oecd.org/eco/workingpapers 


\section{ABSTRACT/RÉSUMÉ \\ Predicting peaks and troughs in real house prices}

OECD work prior to the financial crisis suggested that real prices in several housing markets had become vulnerable to a change in financial and economic conditions, with the risk of a subsequent downturn becoming increasingly possible, as proved to be the case. With corrections in many, but not all, housing markets having now occurred, and, in some countries, prices having rebounded rapidly in the low interest rate environment, the issue of whether prices are now close to another turning point is again of considerable policy interest. As a means of addressing this issue, probit models have been estimated to provide an indication of possible peaks and troughs in real house prices in 2011 and 2012, using data for 20 OECD countries. Predictions based on these models have been reported in OECD Economic Outlook, No. 89 and this paper provides information on the methodology underpinning these predictions.

JEL classification codes: E32; F42; R31

Keywords: house prices; housing bubbles; business cycle

$$
* * * * *
$$

\section{Comment prévoir les fluctuations des prix réels des logements?}

Les travaux menés par l'OCDE avant la crise financière laissaient entendre que les prix réels sur plusieurs marchés du logement ne sauraient résister à une modification des conditions financières et économiques, alors que le risque que leur vulnérabilité n'entraîne une crise économique devenait de plus en plus probable, ainsi que les événements ultérieurs l'ont d'ailleurs démontré. Les prix s'étant désormais rétablis sur un grand nombre, bien que pas sur la totalité, des marchés du logement, et ayant même, dans certains pays, enregistré une remontée rapide favorisée par la faiblesse des taux d'intérêt, la question de savoir s'ils font aujourd'hui face à un nouveau changement de cap mobilise fortement l'intérêt des gouvernements. Pour tenter de répondre à cette question, des modèles probits, dont on estime qu'ils pourraient fournir une indication des fluctuations possibles des prix réels des logements en 2011 et 2012, ont été sollicités et utilisés avec des données concernant 20 pays de l'OCDE. Les prévisions établies sur la base de ces modèles ont été reproduites dans les Perspectives économiques de $l^{\prime} O C D E$, n ${ }^{\circ} 89$, et le présent document donne des informations sur la méthodologie employée à cet effet.

Codes JEL : E32; F42; R31

Mots clés : prix du logement ; bulles immobilières ; cycle économique

Copyright $(\mathcal{C}$ OECD, 2011. All rights reserved. Application for permission to reproduce or translate all, or part of, this material should be made to: Head of Publications Service, OECD, 2 rue André-Pascal, 75775 PARIS CEDEX 16, France. 


\section{Table of contents}

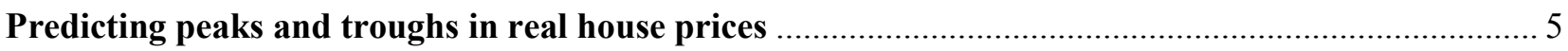

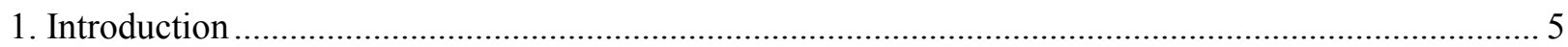

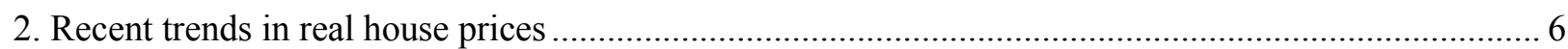

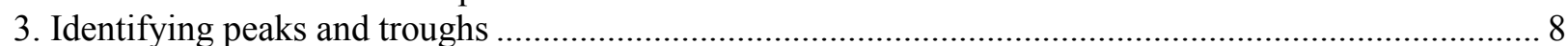

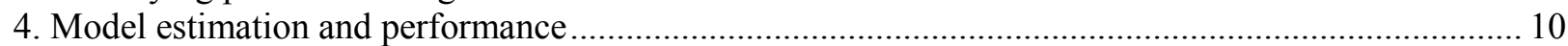

5. Conditional predictions of peaks and troughs in 2011-12 _............................................................. 16

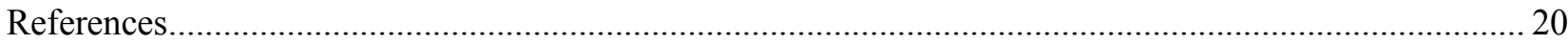

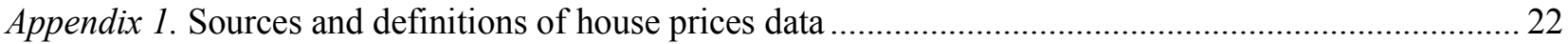

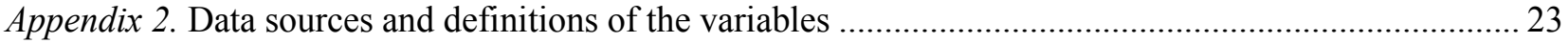

\section{Tables}

1. Probit models for peaks and troughs: Baseline regressions ...................................................... 12

2. Probit models for peaks and troughs: Regressions for the period 1970-2005 .............................. 15

3. Probit model for peaks: Out-of-sample predictions for 2006-10 ….......................................... 16

4. Probit model for troughts: Out-of-sample predictions for 2006-10 …...................................... 16

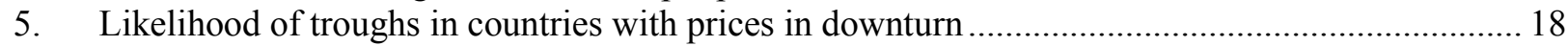

6. Likelihood of peaks in countries with prices in upswing ........................................................... 19

\section{Figures}

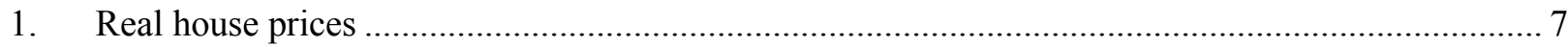

2. Different definitions of local maxima: The case of Belgium ....................................................... 9

3. Number of peaks and troughs in a given year, alternative thresholds......................................... 10

\section{Appendix figures}

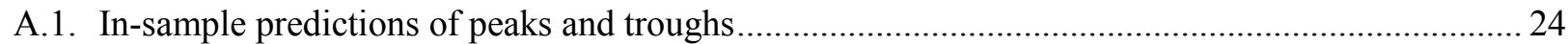

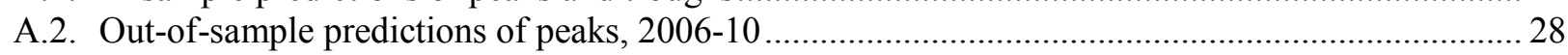

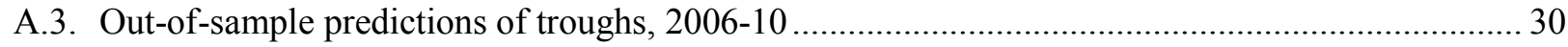


ECO/WKP(2011)51 
ECO/WKP(2011)51

\title{
Predicting peaks and troughs in real house prices
}

\author{
By Linda Rousová and Paul van den Noord ${ }^{1}$
}

\section{Introduction}

Prior to the financial crisis, OECD work (Van den Noord, 2006; Rae and Van den Noord, 2006) suggested that real prices in several housing markets in the OECD area had become vulnerable to a change in financial and economic conditions, with the risk of a subsequent downturn becoming increasingly possible, as proved to be the case. Corrections in many, but not all, housing markets have now occurred, and, in some countries, prices have rebounded rapidly in the current low interest rate environment. The issue of whether prices are now close to another turning point is again of considerable policy interest. For countries where corrections are still ongoing, it is useful to explore when the correction will be completed and recovery will begin. For countries where house prices have rebounded, it is useful to examine when a next peak will be reached.

As a means of addressing this issue, probit models are estimated to provide an indication of possible peaks and troughs in real house prices in 2011 and 2012, using data for 20 OECD countries. The models are calibrated to predict major upswings and downswings in real house prices, defined as cumulative real price increases of at least $15 \%$, or cumulative real price decreases of at least $7 \frac{1}{2} \%$, respectively. We believe that growing deviations from trend or increasing momentum in real house price developments (in either direction), along with fundamentals, are good predictors of such turning points, and our analysis indeed confirms this. Therefore, the explanatory variables used in the models include the estimated gaps between actual and trend real house prices, real house price growth in the recent past, the number of peaks in real house prices in other OECD countries, the interest rate, residential investment and a measure of the overall business cycle. Predictions based on these models were reported in OECD Economic Outlook, No. 89 (OECD, 2011), and this paper provides the background information underpinning these predictions along with some further refinements.

The predictions, which are conditional on projections and risk scenarios embodied in $O E C D$ Economic Outlook, No. 89 (OECD, 2011) for key explanatory variables - e.g. interest rates, residential investment and unemployment - sketch a rather bleak near-term future for real house prices:

- Among the countries in which real house prices peaked prior to or during the financial crisis and have shown corrections since (United States, United Kingdom, Italy, Denmark, Greece, Ireland, Korea, Netherlands, New Zealand and Spain), only the United States and the three smaller euro area countries (Greece, Ireland and Spain) are predicted to possibly see troughs in 2011 or 2012.

- Among the countries in which real house prices are experiencing continued upswings or have rebounded from recent lows (France, Canada, Australia, Belgium, Finland, Norway, Sweden and Switzerland), peaks are predicted to occur before the end of 2012 in all except for Finland and

1. Economics Department, email: linda.rousova@oecd.org and paul.vandennoord@oecd.org. Useful comments received at a lunch seminar a Bruegel, 30 June 2011, in particular by our two discussants Ludger Schuknecht (ECB) and Gabor Koltay (European Commission), are gratefully acknowledged. We are also indebted to Jean-Luc Schneider for his careful review of the paper and valuable comments, and to Patrice Ollivaud for providing the house price database. It goes without saying that all errors and omissions are ours. 
Switzerland, although not uniformly so across different sets of assumptions for the explanatory variables.

- There are two countries, Japan and Germany, where real house prices were in long-term decline when the crisis hit. In the case of Japan, there is some likelihood that real house prices may finally trough in 2011 or 2012. In Germany, where real prices have picked up somewhat since 2008 , the analysis does not signal an impending peak.

Such predictions are, as always, surrounded by uncertainties stemming from estimation errors and possible forecast errors in the explanatory variables. Moreover, the trough model features a weaker out-ofsample performance than the peak model, as will become clear in the discussion below.

\section{Recent trends in real house prices}

When the financial crisis morphed into a full-blown economic crisis in late-2008 real house prices had peaked in the vast majority of OECD countries, following an unprecedented increase since the start of the millennium. In the United States, the correction in real house prices triggered the financial crisis, whereas in Europe and other parts of the OECD area developments in real house prices had become a source of vulnerability exacerbating the impact of the crisis.

The role of housing markets in shaping the financial crisis has been analysed in detail elsewhere, so there is no need to elaborate on this here. What is perhaps less well documented is the widespread (though far from uniform) rebound in real house prices in the immediate aftermath of the crisis. To some extent this is the by-product of the substantial easing of monetary policies in the wake of Lehman's demise in September 2008, and indeed one of the channels through which an even deeper recession was avoided and the recovery engineered. It remains to be seen, however, if this rebound will be sustained once interest rates normalise, which is indeed a main motivation for our study.

Among the 20 countries for which the OECD maintains a quarterly database for real house prices (see Appendix 1 for the list of the countries and the corresponding data sources), it is possible to distinguish four groups of countries in terms of their response to the financial crisis (Figure 1):

- First, relatively sharp rebounds, in the range of 5-15\%, are observed in eight countries (Australia, Belgium, Canada, Finland, France, Norway, Sweden and Switzerland). In three cases (Australia, Canada, Sweden), however, the rebound seems to have run out of steam, possibly in response to monetary policy tightening.

- Second, weaker and already faltering rebounds are observed in four countries (Denmark, Korea, New Zealand and the United Kingdom). In all these cases, the rebound in real house prices seems to have been akin to a "false start" in response to monetary policy easing, possibly masking a continued underlying downturn.

- Third, an outright slide in real house prices is observed in six countries (Greece, Ireland, Italy, Netherlands, Spain and the United States). Among these, the by far sharpest downturns are observed in Greece, Ireland, Spain and the United States, with more moderate downturns in Italy and the Netherlands.

- Fourth, long-term declines in real house prices were ongoing in Germany and Japan when the financial crisis hit, as these were still working off their housing bubbles of the early-1990s. In the case of Germany real house prices seem to be gradually picking up since 2008. 
Figure 1. Real house prices

Index, 2009Q1 = 100
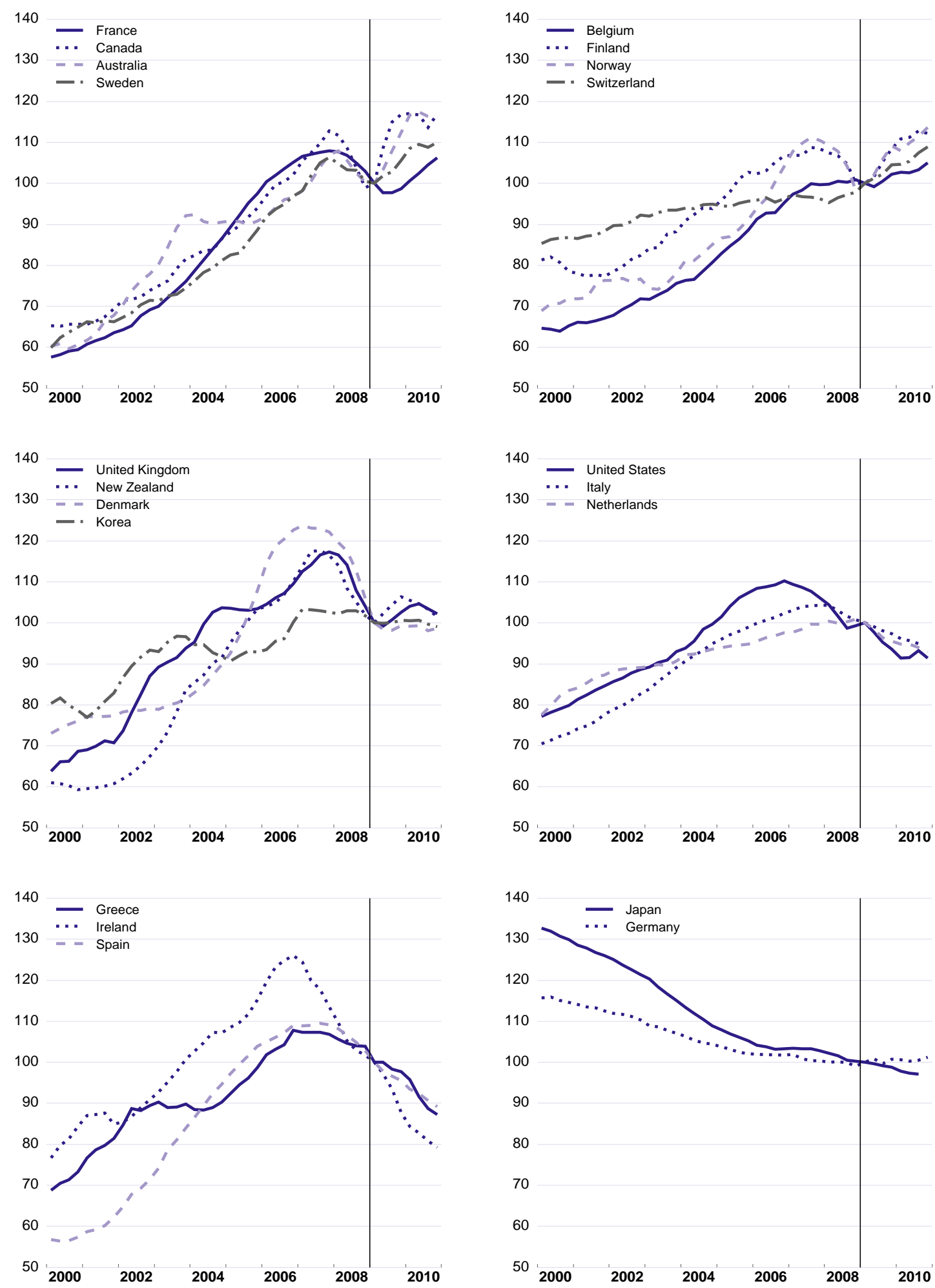

Source: See Appendix 1. 
It is of particular policy interest to be able to predict when the real house price rebounds in the first group of countries above will peak in the near term and, in the cases where real house prices are stalling (second group) or falling (third group) whether they will reach a trough over that period. For this purpose probit models have been estimated to make such predictions - without necessarily providing an indication of "bubbles" inflating or deflating for which the models are not designed. But before such models can be estimated, proper peaks and troughs need to be identified in the historical dataset in a consistent manner.

\section{Identifying peaks and troughs}

Our starting point is the OECD's quarterly database for house prices covering the period 1970-2010 (Appendix 1). Following Girouard et al. (2006) and Van den Noord (2006), we determine peaks and troughs in real house prices in two steps. In the first step, we select local peaks and troughs using a rolling window of a given number of quarters. This is the well-known Bry and Boschan (1971) cycle-dating procedure, as described by Harding (2003). Out of those local peaks and troughs we choose only major peaks and troughs in the second step using a threshold for the magnitude of the downturn and upturn around the turning point with respect to neighbouring peaks or troughs. Below follows a more detailed discussion of this procedure.

\subsection{Step 1: Identification of turning points}

In the first step, the local peaks and troughs in real house prices are identified as local maxima and minima in the series. More formally, a turning point corresponding to a local maximum

$$
=1\left(y_{t}>\operatorname{Max}\left(y_{t-1}, \ldots, y_{t-k}, y_{t+1}, \ldots, y_{t+k}\right)\right)
$$

and a turning point corresponding to a local minimum

$$
=\mathbf{1}\left(y_{t}<\operatorname{Min}\left(y_{t-1}, \ldots, y_{t-k}, y_{t+1}, \ldots, y_{t+k}\right)\right),
$$

where $y_{t}$ is real house price in time $t$ and $\mathbf{1}$ denotes an indicator function. ${ }^{2}$ The arbitrary choice in this step concerns the number of leads and lags used in the formulas as denoted by parameter $k$, or, put differently, the length of the period (corresponding to $2 k+1$ ) on which local maxima or minima are determined.

We assume $k=6$ as used in Girouard et al. (2006) and Van den Noord (2006). We prefer this over the assumption of e.g. $k=2$ used in Crespo Cuaresma (2010). Figure 2 illustrates the case of Belgium, where the overwhelming majority of local maxima found, when using $k=2$, does not capture a plausible turn in the cycle. By contrast, the only local maximum picked up, when using $k=6$, appears to identify the only genuine peak in the series that is followed by a continuous fall in prices and, hence, corresponds to a common perception of a peak from a historical perspective. ${ }^{3}$

\subsection{Step 2: Identification of major peaks and troughs}

Having identified local peaks and troughs using $k=6$, it turns out that some of them still capture relatively small fluctuations in prices of only a few per cent and, hence, should not be considered as major

2. For eventual turning points close to the beginning and end of the period available, missing leads and lags are treated as if satisfying the condition of being above (in the case of local maximum) or below (in the case of local minimum) the eventual turning point. The first and last observations available are never identified as turning points.

3. For the sample as a whole, using $k=2$ we detect 200 and 191 local maxima and minima, respectively and using, $k=6$ the number of turning points decreases by about half to 95 for both local maxima and minima. 
peaks and troughs from a historical perspective. Therefore, we impose in the second step thresholds on minimum price changes prior and after the turning points with respect to the price level of neighbouring turning points that allows us to call some of the local peaks and troughs, respectively, as major peaks and troughs. If a local peak or trough fails to satisfy the threshold rule, it is ignored and we move on to the next local peak or trough and test again.

Figure 2. Different definitions of local maxima: The case of Belgium

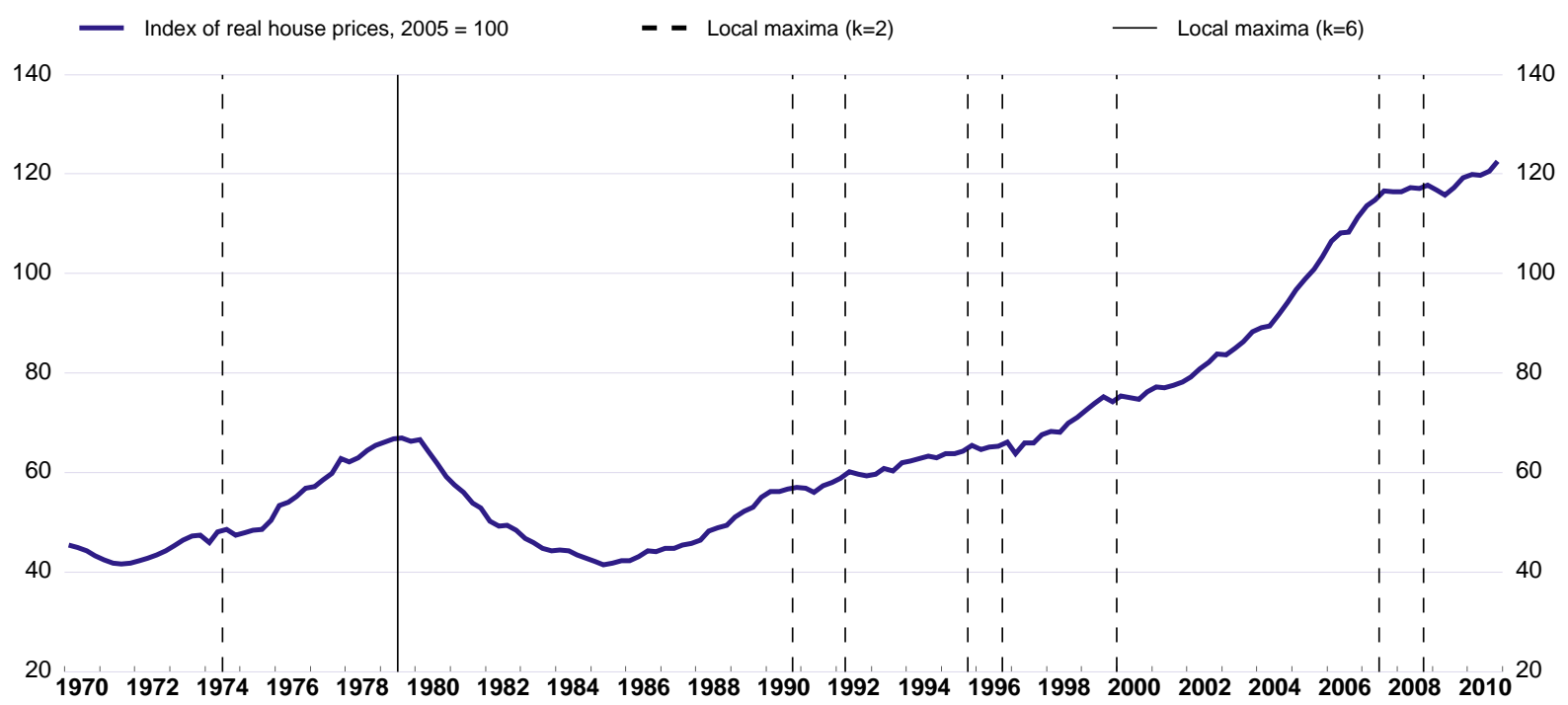

Source: National Bank of Belgium and authors' computations.

As we find that an average price increase in an upturn (i.e., an average increase between a local trough and peak) is $44 \%$, whereas an average price decrease in a downturn (i.e., an average decrease between a local peak and trough) is only $15 \%$, we investigate only combinations of asymmetric thresholds, where a minimum requirement on a price increase is larger than a minimum requirement on a price decrease. In our further analysis we use a combination of thresholds of 15 and $7.5 \%$ for upturns and downturns, respectively, which gives us 49 major peaks and 39 major troughs. ${ }^{4}$ We also experimented with a combination of 10 and $5 \%$ to check if this changes the picture significantly, but this appeared not to be the case. as shown in Figure 3. ${ }^{5}$

On this basis we identify about $2 \frac{1}{2}$ major peaks and two major troughs over the period $1970-2010$ on average per country (see Appendix figure A.1 for the exact dating of major peaks and troughs in individual countries). Hence real house prices appear to follow a low-frequency cyclical pattern, although the length of the cycle is rather irregular, ranging from four to 28 years. ${ }^{6}$ Interestingly, in the period 1995-2005, nearly no major peaks are detected, in line with the prolonged real house price upswings during the "Great

4. For turning points close to the beginning and end of the period, the magnitude of upturns and downturns is calculated using the first and last observations, respectively, instead of using neighbouring peaks and troughs. This implies that major peaks and troughs may be missed towards the beginning and end of the sample period as they can only be identified once more data becomes available.

5. Under that assumption we identify 59 major peaks and 53 major troughs.

6. Accordingly, Cunningham and Kolet (2009) find that housing market expansions have positive duration dependence while contractions seem to have no duration dependence. 
Moderation". The occurrence of major peaks appears to be concentrated in the 1970s and the late1980s/early-1990s (corresponding to the OPEC I and II shocks, the turbulence in the European Monetary System, the Nordic banking crises, the Savings \& Loans crisis in the United States and the Japanese bubble in the early 1990s). An even more striking concentration of peaks is located in the period 2006-07 when more than half of the countries in our sample experienced a major peak. This suggests that peaks in real house prices in this period may have been caused in part by common (global) shocks or cross-border spillover effects (this hypothesis will be tested in our probit analysis). ${ }^{7}$

Figure 3. Number of peaks and troughs in a given year, alternative thresholds ${ }^{1}$

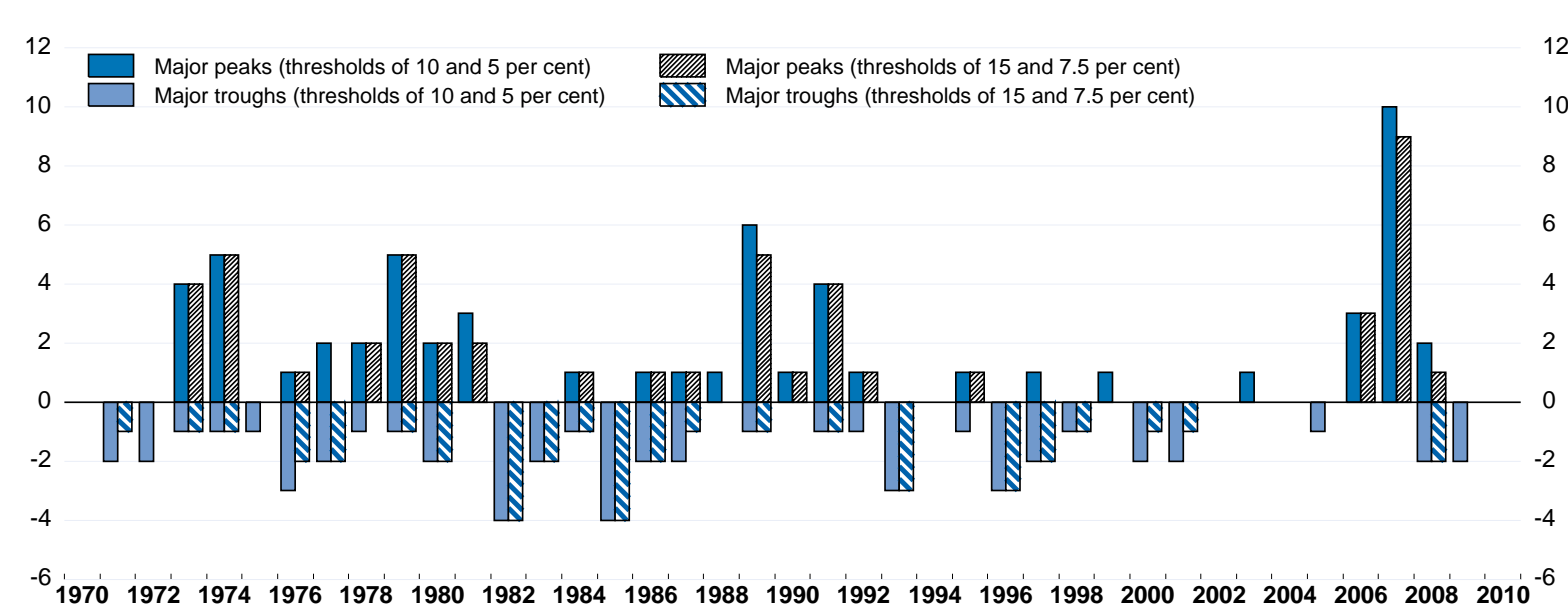

1. The number of peaks (troughs) is shown on a positive (negative) scale.

Source: Authors' computations.

\section{Model estimation and performance}

\subsection{Model specification}

To predict the turning points of the cycle, we build two pooled probit models, one for the occurrence of major peaks and one for the occurrence of major troughs. More formally, let $P_{i t}$ and $T_{i t}$ denote the probability of a major peak and trough, respectively, occurring in country $i$ in period $t$. We assume that

$$
\begin{aligned}
& P_{i t}=\operatorname{Prob}\left(\text { Peak }_{i t}=1 \mid \boldsymbol{X}\right)=\emptyset\left(\boldsymbol{X}^{\prime} \boldsymbol{\beta}\right)=\emptyset\left(\beta_{0}+\beta_{1} x_{1 i t}+\cdots+\beta_{p} x_{p i t}\right) \text { and } \\
& T_{i t}=\operatorname{Prob}\left(\text { Trough }_{i t}=1 \mid \boldsymbol{Z}\right)=\emptyset\left(\boldsymbol{Z}^{\prime} \gamma\right)=\varnothing\left(\gamma_{0}+\gamma_{1} z_{1 i t}+\cdots+\gamma_{q} z_{q i t}\right),
\end{aligned}
$$

where $\emptyset$ is the normal cumulative distribution function and $\mathbf{X}$ and $\mathbf{Z}$ are vectors of explanatory variables for the model for peaks and troughs, respectively. To estimate the parameters $\boldsymbol{\beta}$ and $\gamma$, we use the standard maximum likelihood method. ${ }^{8}$

7. Henceforth major peaks and troughs based on this definition may be referred to as (just) peaks and troughs.

8. We also experimented with estimating an ordered probit model with three different outcomes: troughs, tranquil periods and peaks (ordered accordingly). However, this method turned out to be unsuitable due to different and/or asymmetric role of explanatory variables for the prediction of peaks and troughs. 
As for the explanatory variables, we include two indicators of recent real house price developments; the gap between the logarithm of the actual price and its time trend and the percentage change in real house prices. ${ }^{9}$ We expect that the larger is the price gap (in absolute terms), the more misaligned are the prices and, thus, the higher is the probability of an impending turning point in the cycle, implying a major peak for a positive price gap and a major trough for a negative price gap. Similarly, we expect that the faster is the pace of recent price increases, the more unlikely are further price increases and, hence, the higher is the probability of a major peak and the lower is the probability of a major trough, respectively. ${ }^{10}$

To capture the possibility of housing market contagion across borders (highlighted by Girouard et al. 2006), we include the number of house prices peaks in other OECD countries as an explanatory variable and expect it to enter the model for peaks with a positive coefficient. This variable is expected to capture the spillover effect of loss of households' confidence in housing as a solid investment when house prices in other countries fall as well as the spreading of worsening credit conditions due to the financial contagion triggered by falling house prices elsewhere via cross-border banking. The importance of the latter channel may have risen in recent years as financial markets became more integrated. Alternatively, the variable may also be seen as a proxy for common (unobservable) shocks affecting house price developments across countries. For example, innovation in financial (and mortgage) markets, having been a common trend in many OECD countries, may account for this (see, e.g. Andrews, 2010 and Agnello and Schuknecht, 2011).

To capture borrowing conditions faced by households, we include two measures of developments in nominal long-term interest rates in the models; the level (in logarithm) and the percentage change of the interest rates. As high and/or fast growing interest rates drive up the costs of loans, they are likely to increase the probability of peaks and decrease the probability of troughs. Since the impact of interest rate hikes on financing constraints is highly non-linear (Van den Noord, 2006), we include the logarithm rather than the level of the interest rates in the models. As the service burden of a given level of mortgage debt is less in a high-inflation environment, a higher inflation rate is likely to increase the probability of troughs and decrease the probability of peaks. Therefore, we also include inflation as an explanatory variable.

The share of residential investment in GDP can be used as a proxy for housing supply. Its increase is likely to contribute to the nearing downturn in the housing cycle, hence increasing the probability of a peak, while decreasing the probability of a trough. ${ }^{11}$ Finally, we include the unemployment gap in the models to capture the overall business cycle and expect that when the unemployment gap is high and hence the economy sluggish, a housing peak is less likely whereas the probability of a trough nearing increases. Data sources and the definition of the variables used are reported in Appendix 2.

\subsection{Baseline estimation results}

The baseline results are obtained using a general-to-specific methodology. We started with the full set of explanatory variables listed above and tested several others, such as the level and volatility of share and oil prices, the current account balance, measures of cross-border capital flows and the number of troughs in other OECD countries. The regressors are averaged over two quarters (the quarter prior to a peak or trough and the same quarter when a peak or trough occurs) ${ }^{12}$, as this choice appears to lead to plausible models in

9. Instead of a simple time trend, we also experimented with a trend based on fundamentals such as population and (potential) GDP per capita and used it for the construction of an alternative price gap, but the resulting models achieved a lower explanatory power than the baseline models.

10. Fraser et al. (2008) found such a "momentum effect" in housing markets, with agents buying after price increases (selling after price falls), thus heightening the probability of a major correction down the road.

11. According to Gerdesmeier et al. (2009) the investment-to-GDP ratio is a powerful predictor of asset price busts alongside financial variables.

12. There is an exception to this rule for one regressor in the trough model, as explained below. 
terms of both significance of the explanatory variables and in-sample-fit performance of the models. Only the regressors that were found significant and robust to different model specifications were kept in the baseline models reported in Table 1.

Table 1. Probit models for peaks and troughs: Baseline regressions ${ }^{1}$

\begin{tabular}{|c|c|c|c|c|}
\hline \multirow[t]{2}{*}{ Dependent variable: } & \multicolumn{2}{|c|}{$\begin{array}{c}(1) \\
\text { Peaks } \\
\end{array}$} & \multicolumn{2}{|c|}{$\begin{array}{l}\text { (2) } \\
\text { Troughs }\end{array}$} \\
\hline & Coefficients & $\begin{array}{l}\text { Marginal } \\
\text { effects }^{2}\end{array}$ & Coefficients & $\begin{array}{c}\text { Marginal } \\
\text { effects }^{2}\end{array}$ \\
\hline Real house price gap & $\begin{array}{l}3.59^{* * *} \\
(0.00)\end{array}$ & $\begin{array}{l}2.79^{* * *} \\
(0.00)\end{array}$ & $\begin{array}{c}-3.19 * * * \\
(0.00)\end{array}$ & $\begin{array}{c}-1.44^{* * *} \\
(0.01)\end{array}$ \\
\hline Real house price (percentage change) & $\begin{array}{c}0.074^{* * *} \\
(0.00)\end{array}$ & $\begin{array}{c}0.058^{* * *} \\
(0.01)\end{array}$ & $\begin{array}{c}-0.28^{* * *} \\
(0.00)\end{array}$ & $\begin{array}{c}-0.13^{* * *} \\
(0.01)\end{array}$ \\
\hline Number of peaks in other OECD countries & $\begin{array}{c}0.32^{* * *} \\
(0.00)\end{array}$ & $\begin{array}{c}0.25^{\star * *} \\
(0.01)\end{array}$ & & \\
\hline Long-term interest rate $(\mathrm{log})$ & $\begin{array}{c}0.53^{* * *} \\
(0.00)\end{array}$ & $\begin{array}{c}0.80^{* * *} \\
(0.01)\end{array}$ & & \\
\hline Long-term interest rate (percentage change) & & & $\begin{array}{c}-0.044^{* *} \\
(0.02)\end{array}$ & $\begin{array}{c}-0.020 * * \\
(0.02)\end{array}$ \\
\hline Inflation rate (\%) & & & $\begin{array}{c}0.043^{* *} \\
(0.02)\end{array}$ & $\begin{array}{l}0.02^{* *} \\
(0.03)\end{array}$ \\
\hline Residential investment (as \% of GDP) & $\begin{array}{l}0.074^{* *} \\
(0.02)\end{array}$ & $\begin{array}{l}0.058^{* *} \\
(0.04)\end{array}$ & & \\
\hline Unemployment gap (\%) & $\begin{array}{c}-0.083^{*} \\
(0.07)\end{array}$ & $\begin{array}{c}-0.065^{*} \\
(0.10)\end{array}$ & & \\
\hline Unemployment gap (\%, two years lag) ${ }^{3}$ & & & $\begin{array}{l}0.10^{\star *} \\
(0.02)\end{array}$ & $\begin{array}{l}0.046^{*} \\
(0.08)\end{array}$ \\
\hline Constant & $\begin{array}{c}-4.34^{* * *} \\
(0.00)\end{array}$ & . & $\begin{array}{c}-3.09^{* * *} \\
(0.00)\end{array}$ & $\cdot$ \\
\hline Observations & \multicolumn{2}{|c|}{3,038} & \multicolumn{2}{|c|}{3,003} \\
\hline Correctly classified (\%) & \multicolumn{2}{|c|}{81.0} & \multicolumn{2}{|c|}{81.6} \\
\hline Correctly classified peaks/troughs (\%) & \multicolumn{2}{|c|}{85.4} & \multicolumn{2}{|c|}{92.1} \\
\hline Correctly classified non-peaks/non-troughs (\%) & \multicolumn{2}{|c|}{80.9} & \multicolumn{2}{|c|}{81.4} \\
\hline
\end{tabular}

1. ${ }^{* * *},{ }^{* *},{ }^{*}$ denote significance at the 1,5 , and $10 \%$ significance levels, res pectively. P-values (in parentheses) are based on robust standard errors. Explanatory variables are averaged over two quarters (the quarter prior to a peak/trough and the same quarter when a peak/trough occurs), if not stated differently.

2. Refer to changes in percentage points, not in probabilities, and evaluated at the means of the explanatory variables. Semi-elasticity rather than a marginal effect is reported for the log of the long-term interest rate.

3. Averaged over four quarters.

Source: Authors' estimations.

The signs of the estimated coefficients are in line with our expectations. In particular, the results suggest that recent price developments play a major role in determining the probability of peaks and troughs: the higher the price level (as measured by the price gap) and the faster the pace of price increase, the higher the probability of a peak and the lower the probability of a trough. ${ }^{13}$ The probability of a peak

13. The estimated coefficients of the price gap and percentage change in real house prices may suffer from an endogeneity problem as the two explanatory variables partly depend on the left-hand variable, i.e. the presence of a peak or trough. However, reverse causality is of little concern because a peak or trough will affect the price developments only with a lag, and the price gap and change in real house prices, in turn, are 
also significantly increases with the number of peaks in other countries. This result signals the possible presence of spillover effects across OECD countries in the case of peaking house prices. An analogous result could not be found in the model for troughs.

The developments of long-term interest rates play a significant role for both peaks and troughs, too. The probability of a trough appears to be driven by the pace of change rather than by the level of long-term interest rates, as the estimates suggest that the faster is the decrease in long-term interest rates, the higher is the probability of a trough. A possible explanation might read as follows. The level of the interest rate may matter more for the affordability of housing when house prices are high than when they are low. So it makes sense that the level of the interest rate is a good predictor of peaks but not of troughs. By contrast, with the housing market in a slump, a decline in the interest rate may be seen as a positive signal by market participants and thus increase the probability of a trough. An increase in the interest rate when prices are high may have the equivalent effect on peaks, but the level effect seems to be dominant. In other words, in upswings the affordability effect dominates and in downswings the signalling effect dominates.

Being in a high inflation environment appears to increase the probability of a trough, but we do not find any significant effect of inflation on the probability of a peak. Apparently, a housing downswing is more likely to stop if inflation picks up and the mortgage debt burden likely to erode as a result. The reverse does not seem to work for peaks: lower inflation during a housing boom does not seem to impede the continuation of the boom.

Conversely, the share of residential investment in GDP appears to matter only for the probability of peaks: a residential construction boom increases the likelihood of real house prices peaking. This is as expected as an increase in housing supply may absorb housing demand and therefore ease price tensions. An analogous effect is not found for troughs, which may be interpreted as reflecting that the housing supply constraint is binding in an upswing but not in a downswing.

The business cycle, as measured by the unemployment gap, turns out to be important for peaks and troughs alike. In periods of low (or negative) cyclical unemployment the probability of a housing boom peaking tends to be high, suggesting a positive correlation between the housing cycle and the overall business cycle (confirming earlier findings by Girouard and Blöndal, 2001). However, the business cycle effect on the probability of a trough materialises with a certain delay, as the unemployment gap was found to be significant in the model for troughs only with a two years distributed lag. So apparently it takes more time for a recovery in the overall business cycle to trickle trough in a recovery in the housing cycle.

To evaluate the fit of the model for peaks, we calculate three ratios as follows:

$$
\begin{aligned}
& \text { Percentage of correctly classified peaks }=\frac{\text { \#orractlypredictedpeaks }}{\# \text { called peaks }} * 100 \% \\
& \text { Percentage of correctly classified non-peaks }=\frac{\text { \#correotly predieted non-peaks }}{\# \text { called non-parks }} * 100 \%
\end{aligned}
$$

and percentage of all correctly classified observations as the ratio of the sum of the nominators in (1) and (2) to the total number of observations. We proceed analogously for the model for troughs.

Nevertheless, these ratios depend on the cut-off probability level that is used for predicting a peak (trough). Moreover, the set-up of the cut-off level leads to the following trade-off: The higher is the cut-off level, the smaller is the ratio in (1), but the higher is the ratio in (2). Following Furceri et al. (2011) and Beck et al. (2006), we use the unconditional probability of the occurrence of a peak (trough) which is

again partly lagged in the model. In addition, eventual endogeneity problems do not matter for prediction purposes. 
calculated as the percentage of the total number of called peaks (troughs) in the total number of observations in the estimation sample. ${ }^{14}$ This choice leads to relatively similar rates of success across the three different ratios. In particular, the three ratios in both models presented in Table lexceeds $81 \%$ which appears to be a satisfactory fit (see Appendix figure A.1 for the fit of the models for individual countries).

\subsection{Out-of-sample performance}

To better assess the performance of the baseline probit models, we also investigate their out-of-sample performance. In particular, we estimate the baseline models on a shorter time span using only years 19702005. Leaving out the last five years, including the years of the recent financial crisis, enables us to assess whether our models would have been able to detect the recent wide-spread housing busts and subsequent recoveries.

When using the shorter time span, all estimated coefficients retain their signs in both models (Table 2). Nevertheless, we detect two important differences to the baseline model for peaks. First of all, the coefficient of the spillover effects as measured by the number of peaks in other OECD countries becomes insignificant. Second, the coefficient of the long-term interest rate significantly increases to 0.92 as compared to the coefficient of 0.53 in the baseline model for peaks.

This could be tentatively interpreted as follows. Mortgage markets have innovated while financial and banking systems globalised. This has a number of possible ramifications. First, increases in (domestic) interest rates may be more easily circumvented by importing credit from abroad via banks that operate in several countries. ${ }^{15}$ As a result, a housing downturn and associated financial stress in creditor countries can spill over to housing markets in debtor countries via a bank lending channel. Second, with financial globalisation, sudden changes in sentiment, including in housing markets, can more easily spill over to other countries as well. Finally, innovation in mortgage markets may include schemes to cushion the effect of interest rate increases via longer maturities of mortgages or hedging, which could explain the lower interest rate sensitivity in the more recent period.

The in-sample performance of both models remains satisfactory, since more than $81 \%$ of observations are correctly classified. However, as expected, the out-of-sample performance of the models as tested on the period 2006-2010 is somewhat weaker. The model for peaks classifies $63 \%$ of all observations correctly, though the rate of success is nearly $70 \%$ in the case of classification of peaks (Table 3 ). More specifically, out of the 13 peaks experienced by the countries in the period 2006-10 nine peaks are correctly predicted by the model. Those are a peak in Ireland in 2006 and peaks in Canada, Denmark, Finland, France, Ireland, Norway, New Zealand, Spain and the United Kingdom in 2007 (Appendix figure A.2). By contrast, the model fails to predict four peaks, namely, peaks in Greece and the United States in 2006, a peak in Italy in 2007 and a peak in the Netherlands in 2008.

These findings need to be qualified in a number of respects. Most importantly, cases where a peak is predicted but not called tend to be clustered around the quarter in which a peak is called. A closer look also reveals that the non-prediction of the peaks in the United States and Italy is only border-line as the predicted probabilities are elevated around the peaks and relatively close to the cut-off level used for the detection of peaks. ${ }^{16}$ A peak in the Netherlands is predicted throughout 2007, but materializes in 2008.

14. The corresponding numbers are 1.6 and $1.3 \%$ for the model for peaks and troughs, respectively.

15. According to Setzer et al. (2011) demonstrate that this channel gained strength in Europe following the creation of the single currency.

16. Most US house price models break down in the mid-2000s, due to the omission of exogenous changes in credit constraints facing first-time home-buyers, see Duca et al. (2010, 2011). The case of Italy is less clear-cut. 
These examples suggest that, unlike the occurrence of a peak per se, it is difficult to predict the exact timing of a peak. The model seriously fails to predict a peak in Greece in 2006, but a plausible explanation

Table 2. Probit models for peaks and troughs: Regressions for the period 1970-2005 ${ }^{1}$

\begin{tabular}{|c|c|c|c|c|}
\hline & \multicolumn{2}{|c|}{$\begin{array}{c}(1) \\
\text { Peaks }\end{array}$} & \multicolumn{2}{|c|}{$\begin{array}{c}(2) \\
\text { Troughs }\end{array}$} \\
\hline & Coefficients & $\begin{array}{l}\text { Marginal } \\
\text { effects }^{2}\end{array}$ & Coefficients & $\begin{array}{l}\text { Marginal } \\
\text { effects }^{2}\end{array}$ \\
\hline Real house price gap & $\begin{array}{c}3.90^{* * *} \\
(0.00)\end{array}$ & $\begin{array}{c}2.19^{\star \star *} \\
(0.00)\end{array}$ & $\begin{array}{c}-4.17^{* * *} \\
(0.00)\end{array}$ & $\begin{array}{c}-1.85^{\star * *} \\
(0.01)\end{array}$ \\
\hline Real house price (percentage change) & $\begin{array}{c}0.077^{* * *} \\
(0.00)\end{array}$ & $\begin{array}{c}0.043^{* *} \\
(0.02)\end{array}$ & $\begin{array}{c}-0.26^{* * *} \\
(0.00)\end{array}$ & $\begin{array}{c}-0.12^{* *} \\
(0.01)\end{array}$ \\
\hline Number of peaks in other OECD countries & $\begin{array}{c}0.15 \\
(0.29)\end{array}$ & $\begin{array}{l}0.085 \\
(0.29)\end{array}$ & & \\
\hline Long-term interest rate $(\mathrm{log})$ & $\begin{array}{c}0.92^{* * *} \\
(0.00)\end{array}$ & $\begin{array}{l}1.06^{\star *} \\
(0.01)\end{array}$ & & \\
\hline Long-term interest rate (percentage change) & & & $\begin{array}{c}-0.042^{* *} \\
(0.03)\end{array}$ & $\begin{array}{c}-0.019 * * \\
(0.04)\end{array}$ \\
\hline Inflation rate $(\%)$ & & & $\begin{array}{c}0.040^{* *} \\
(0.03)\end{array}$ & $\begin{array}{c}0.018^{* *} \\
(0.02)\end{array}$ \\
\hline Residential investment (as \% of GDP) & $\begin{array}{l}0.084^{*} \\
(0.05)\end{array}$ & $\begin{array}{l}0.047^{*} \\
(0.08)\end{array}$ & & \\
\hline Unemployment gap (\%) & $\begin{array}{c}-0.089^{*} \\
(0.06)\end{array}$ & $\begin{array}{c}-0.050^{*} \\
(0.09)\end{array}$ & & \\
\hline Unemployment gap (\%, two years lag $)^{3}$ & & & $\begin{array}{l}0.076 \\
(0.11)\end{array}$ & $\begin{array}{l}0.034 \\
(0.18)\end{array}$ \\
\hline Constant & $\begin{array}{c}-5.31^{* * *} \\
(0.00)\end{array}$ & . & $\begin{array}{c}-3.10^{* * *} \\
(0.00)\end{array}$ & . \\
\hline Observations & 26 & & 26 & \\
\hline Correctly classified $(\%)$ & 82 & & 81 & \\
\hline Correctly classified peaks/troughs (\%) & 85 & & 86 & \\
\hline Correctly classified non-peaks/non-troughs (\%) & 82 & & 81 & \\
\hline
\end{tabular}

1. ${ }^{* * *},{ }^{* *},{ }^{*}$ denote significance at the 1,5 , and $10 \%$ significance levels, res pectively. P-values (in parentheses) are based on robust standard errors. Explanatory variables are averaged over two quarters (the quarter prior to a peak/trough and the same quarter when a peak/trough occurs), if not stated differently.

2. Refer to changes in percentage points, not in probabilities, and evaluated at the means of the explanatory variables. Semi-elasticity is reported for the log of the long-term interest rate.

3. Averaged over four quarters.

Source: Authors' estimations. 
is that, as the house price data for Greece starts only in 1997, the estimated time trend for Greece is biased upwards by the pre-crisis bubble. This in turn leads to an underestimated price gap entering the model and, thus, to under-prediction of a peak (and possibly an over-prediction of a through further down the road).

Table 3. Probit model for peaks: Out-of-sample predictions for 2006-10 ${ }^{1}$

\begin{tabular}{|c|c|c|c|}
\hline Prediction \Call & Peak not called & Peak called & Total \\
\hline Peak not predicted & $240(62 \%)$ & $4(31 \%)$ & $154(61 \%)$ \\
\hline Peak predicted & $145(38 \%)$ & $9(69 \%)$ & $398(63 \%)^{2}$ \\
\hline Total & $385(100 \%)$ & $13(100 \%)$ & 150 \\
\hline
\end{tabular}

1. Column percentages reported in parentheses, if not stated differently.

2. Refers to the total percentage of correctly classified observations.

Source: Authors' computations based on the model for peaks in Table 2.

The out-of-sample performance of the model for troughs is more difficult to assess, because only for two countries, Canada and Norway, a major trough is called in the period 2006-10. In both cases, the predicted probabilities rose somewhat but not enough to predict a trough (Table 4 and Appendix figure A.3). On the other hand, the model for troughs classified correctly $91 \%$ of observations where a through was not called. The upshot is that the model seems to be able to allow relatively robust predictions of troughs not occurring, but less so of troughs occurring. In addition, with more observations becoming available, a major trough may eventually be called in some cases, where it is predicted by the model. For instance, the model predicts a trough in Germany in the last quarter of 2008, when a local minimum over the period 2006-10 can be observed, but the subsequent increase in house prices has not been sufficient yet to call a major trough.

Table 4. Probit model for troughts: Out-of-sample predictions for $2006-10^{1}$

\begin{tabular}{|c|c|c|c|}
\hline Prediction \Call & Trough not called & Trough called & Total \\
\hline Trough not predicted & $361(91 \%)$ & $2(100 \%)$ & $363(91 \%)$ \\
\hline Trough predicted & $35(9 \%)$ & $0(0 \%)$ & $35(9 \%)$ \\
\hline Total & $396(100 \%)$ & $2(100 \%)$ & $398(91 \%)^{2}$ \\
\hline
\end{tabular}

1. Column percentages reported in parentheses, if not stated differently.

2. Refers to the total percentage of correctly classified observations.

Source: Authors' computations based on the model for troughs in Table 2.

\section{Conditional predictions of peaks and troughs in 2011-12}

To obtain predictions with the two models for the years 2011 and 2012, two sets of alternative combinations of assumptions (scenarios) have been used. In the first scenario real house prices are assumed to be constant from the last observed quarter (in most cases 2010Q4) onwards. In the second scenario, real house prices are assumed to either fall or increase by $10 \%$ over the projection period depending on whether prices were falling (after a peak has been called) or rising (after a trough has been 
called) up to the last observed quarter. ${ }^{17}$ These assumptions are necessary to construct the house price gap and house price momentum variables for the projection period. In both scenarios the path of all the other explanatory variables is set to be the same as in OECD Economic Outlook, No. 89 (OECD, 2011). ${ }^{18}$

Comparing the two scenarios provides some indication whether a further real price increase (decline) would be sufficient for a peak (trough) to occur in the projection period. We recall though that false alarms for peaks and (non-) troughs cannot be ruled out, so these predictions always need to be judged in combination with other sources of information. Moreover, the methodology cannot rule out the possibility that peaks or troughs in the most recent period are missed given that the most recent cycles are incomplete. ${ }^{19}$ The main results are:

- The countries in which real house prices peaked prior to or during the financial crisis and have been in a downturn since are: the United States, United Kingdom, Italy, Greece, Denmark, Ireland, Korea, Netherlands, New Zealand and Spain (Table 5).$^{20}$ Of these only the United States and the three smaller euro area countries (Greece, Ireland and Spain) are predicted to possibly see troughs in 2011 or 2012. For the United States a trough would be likely though only towards the end of the projection period and in the second scenario - i.e. following a further decline in real house prices trough 2011 and 2012. For the three euro area countries the model predicts a significant probability of a trough throughout the projection period in both scenarios, but it should be noted that this is based on an assumed fall in bond yield spreads against the German benchmark. $^{21}$

- The countries that are currently observing upswings in real house prices which have not yet been completed are France, Canada, Australia, Belgium, Finland, Norway, Sweden and Switzerland (Table 6). Peaks are predicted to be possible in all these countries except for Finland and Switzerland. For Sweden peaks are predicted in both scenarios, whereas for the other countries peaks are predicted only in the second scenario and not before 2012, i.e. after real house prices have gone through some further increases in 2011. Only in case of Australia, a peak is signalled already in 2011, though only in the second scenario.

- There are two countries, Japan and Germany, where real house prices were in long-term decline when the crisis hit. In the case of Japan, there is some likelihood that real house prices may finally trough in 2011 or 2012 (Table 5). In Germany, where real prices have picked up somewhat since 2008 , the analysis does not signal a peak (Table 6).

17. Korea is included in the former category even if a major peak has not been called formally yet and, analogously, Germany is assumed to be in the latter category even if a major trough has not been called formally yet.

18. The spill-over variable (the number of peaks in other OECD countries) is assumed to be zero to reflect the uncertainty of these predictions. So, in some sense, the prediction of peaks in this exercise may be qualified as "conservative", i.e. disregarding cross-border contagion effects.

19. On the other hand, when we use our scenarios as "data", no data point past any last called peak or trough qualifies as a new peak or trough. So the scenarios, the predictions and the historical data are mutually consistent.

20. As noted, Korea has not formally peaked yet, but has been treated as if it has done so.

21. Moreover, in the case of Greece, the out-of-sample prediction properties may be biased towards signalling a trough due to the shorter estimation period (see Section 4). 
ECO/WKP(2011)51

Table 5. Likelihood of troughs in countries with prices in downturn

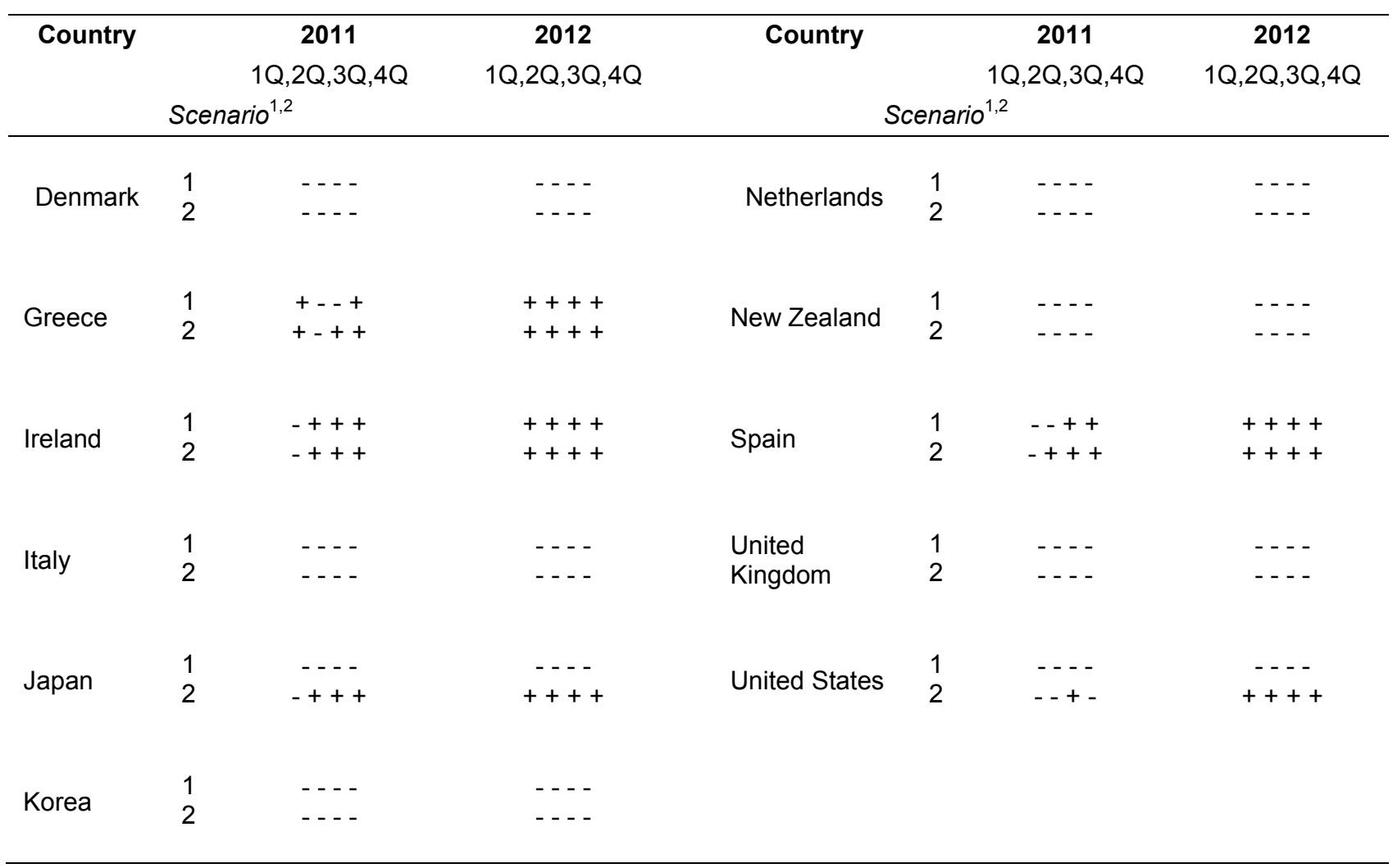

Note: + indicates a trough based on the cut-off level corresponding to the unconditional probability of a trough.

1. Scenario 1 assumes constant real house prices over the projection period.

2. Scenario 2 assumes falling real house prices by $10 \%$ over the projection period.

Source: Authors' computations based on the model for troughs reported in Table 1.

From this exercise emerges the following overall picture. Most countries that are currently experiencing upswings in real house prices are expected to see their housing cycle turn down in 2012 on the basis of the assumptions embodied in OECD Economic Outlook, No. 89 (OECD, 2011). Most countries that are currently experiencing downturns in real house prices are not expected to see troughs in the projection period, possibly with the exception of the United States along with the "peripheral" euro area countries - the latter provided the sovereign debt crisis is contained. 
ECO/WKP(2011)51

Table 6. Likelihood of peaks in countries with prices in upswing

\begin{tabular}{|c|c|c|c|c|c|c|c|}
\hline \multirow[t]{2}{*}{ Country } & & 2011 & 2012 & \multicolumn{2}{|l|}{ Country } & 2011 & 2012 \\
\hline & & $1 \mathrm{Q}, 2 \mathrm{Q}, 3 \mathrm{Q}, 4 \mathrm{Q}$ & $1 \mathrm{Q}, 2 \mathrm{Q}, 3 \mathrm{Q}, 4 \mathrm{Q}$ & & & $1 \mathrm{Q}, 2 \mathrm{Q}, 3 \mathrm{Q}, 4 \mathrm{Q}$ & $1 \mathrm{Q}, 2 \mathrm{Q}, 3 \mathrm{Q}, 4 \mathrm{Q}$ \\
\hline \multicolumn{2}{|c|}{ Scenario $^{1,2}$} & \multicolumn{6}{|c|}{ Scenario ${ }^{1,2}$} \\
\hline Australia & $\begin{array}{l}1 \\
2\end{array}$ & $\begin{array}{c}--- \\
-+++\end{array}$ & $\begin{array}{c}--- \\
++++\end{array}$ & Norway & $\begin{array}{l}1 \\
2\end{array}$ & - - - - & $\begin{array}{l}--- \\
--++\end{array}$ \\
\hline Belgium & $\begin{array}{l}1 \\
2\end{array}$ & - - - & $\begin{array}{c}--- \\
-+++\end{array}$ & Sweden & $\begin{array}{l}1 \\
2\end{array}$ & $\begin{array}{l}-+++ \\
++++\end{array}$ & $\begin{array}{l}++++ \\
++++\end{array}$ \\
\hline Canada & $\begin{array}{l}1 \\
2\end{array}$ & --- & $\begin{array}{l}--- \\
-- \\
-\end{array}$ & Switzerland & $\begin{array}{l}1 \\
2\end{array}$ & 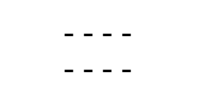 & $-\cdots$ \\
\hline Finland & $\begin{array}{l}1 \\
2\end{array}$ & --- & --- & Germany & $\begin{array}{l}1 \\
2\end{array}$ & --- & --- \\
\hline France & $\begin{array}{l}1 \\
2\end{array}$ & --- & $\begin{array}{l}--- \\
--++\end{array}$ & & & & \\
\hline
\end{tabular}

Note: + indicates a peak based on the cut-off level corresponding to the unconditional probability of a peak.

1. Scenario 1 assumes constant real house prices over the projection period.

2. Scenario 2 assumes increasing real house prices by $10 \%$ over the projection period.

Source: Authors' computations based on the model for peaks reported in Table 1. 


\section{References}

Agnello, L. and L. Schuknecht (2011), "Booms and Busts in Housing Markets: Determinants and Implications", Journal of Housing Economics (forthcoming).

Andrews, D. (2010), "Real House Prices in OECD Countries: The Role of Demand Shocks and Structural and Policy Factors", OECD Economics Department Working Papers, No. 831.

Beck, T. H. L., A. Demirgüç-Kunt and R. Levine (2006), "Bank Concentration, Competition and Crises: First Results", Journal of Banking and Finance, Vol. 30, pp. 1581-1603.

Bry, G. and C. Boschan (1971), Cyclical Analysis of Time Series: Selected Procedures and ComputerPrograms, National Bureau of Economic Research, NewYork.

Crespo Cuaresma, J. (2010), "Can Emerging Asset Price Bubbles be Detected?", OECD Economics Department Working Paper, No.772.

Cunningham, R. and I. Kolet (2007), "Housing Market Cycles and Duration Dependence in the United States and Canada", Bank of Canada Working Paper, No. 2007-2.

Duca, J.V., J. Moellbauer and A.Murphy (2010), "Housing Markets and the Financial Crisis of 2007-2009: Lessons for the Future", Journal of Financial Stability, Vol. 6, pp. 203-217.

Duca, J.V., J. Moellbauer and A.Murphy (2011), "House Prices and Credit Constraints: Making Sense of the U.S. Experience”, Economic Journal, Vol. 121, pp. 533-551.

Fraser, P., M. Hoesli, and L. McAlevey (2008), "A Comparative Analysis of House Prices and Bubbles in the U.K and New Zealand." Pacific Rim Property Research Journal, Vol. 13.

Furceri, D., S. Guichard and E. Rusticelli (2011), "Episodes of Large Capital Inflows and the Likelihood of Banking and Currency Crises and Sudden Stops", OECD Economics Department Working Paper, No.865.

Gerdesmeier, D., H-E. Reimers and B. Roffia (2009), "Asset Price Misalignments and the Role of Money and Credit”, ECB Working Paper Series, No. 1068.

Girouard, N. and S. Blöndal (2001). "House Prices and Economic Activity", OECD Economic Department Working Paper, No. 279.

Girouard, N., M. Kennedy, P. van den Noord and C. André (2006), "Recent House Price Developments: the Role of Fundamentals", OECD Economics Department Working Paper, No. 475.

Harding, D. (2003), "Towards an Econometric Foundation for Turning Point Based Analysis of Dynamic Processes", Paper presented at the 2003 Australian Meeting of the Econometric Society. 
OECD (2011), OECD Economic Outlook, No. 89, Paris.

Rae, D. and P. van den Noord (2006), "Ireland's Housing Boom: What has Driven it and Have Prices Overshot?", OECD Economics Department Working Paper, No. 492.

Setzer R., P. van den Noord and G.B. Wolff (2011), "Heterogeneity in Money Holdings across Euro Area Countries: the Housing Channel", European Journal of Political Economy (forthcoming).

Van den Noord, P. (2006), "Are House Prices Nearing a Peak? A Probit Analysis for 17 OECD Countries", OECD Economics Department Working Paper, No. 488. 


\section{Appendix 1. Sources and definitions of house prices data}

\begin{tabular}{|c|c|c|c|c|}
\hline Country & House price definition & $\begin{array}{l}\text { Seasonal } \\
\text { adjust- } \\
\text { ment }\end{array}$ & Source & $\begin{array}{l}\text { Available time } \\
\text { span }\end{array}$ \\
\hline Australia & $\begin{array}{l}\text { Index of a weighted average of } 8 \\
\text { capital cities }\end{array}$ & No & $\begin{array}{l}\text { Australia Bureau } \\
\text { of Statistics }\end{array}$ & 1970Q1-2010Q4 \\
\hline Belgium & Residential property prices & No & $\begin{array}{l}\text { National Bank of } \\
\text { Belgium }\end{array}$ & 1970Q1-2010Q4 \\
\hline Canada & $\begin{array}{l}\text { Multiple listing series, average price } \\
\text { in Canadian dollars }\end{array}$ & Yes & $\begin{array}{l}\text { Ministry of } \\
\text { Finance }\end{array}$ & 1970Q1-2010Q4 \\
\hline Denmark & Index of one-family house sold & No & $\begin{array}{l}\text { Statistics } \\
\text { Denmark }\end{array}$ & 1970Q1-2010Q4 \\
\hline Finland & $\begin{array}{l}\text { Housing prices in metropolitan area, } \\
\text { debt free, price per } \mathrm{m} 2\end{array}$ & No & Bank of Finland & 1970Q1-2010Q4 \\
\hline France & Indice de prix des logements anciens & No & INSEE & 1970Q1-2010Q4 \\
\hline Germany & $\begin{array}{l}\text { Index for total Germany, total re- } \\
\text { sales }\end{array}$ & -- & Bundesbank & 1970Q1-2010Q4 \\
\hline Greece & $\begin{array}{l}\text { Index of prices dwellings, urban } \\
\text { areas }\end{array}$ & No & Bank of Greece & 1997Q1-2010Q4 \\
\hline Italy & $\begin{array}{l}\text { Media } 13 \text { area urbane numeri indice } \\
\text { dei prezzi medi di abitazioni, usate }\end{array}$ & No & Nomisma & 1970Q1-2010Q3 \\
\hline Ireland & Second hand houses & Yes & $\begin{array}{l}\text { Central Statistics } \\
\text { Office }\end{array}$ & 1970Q1-2010Q4 \\
\hline Japan & Nationwide urban land price index & No & $\begin{array}{l}\text { Japan Real Estate } \\
\text { Institute }\end{array}$ & 1970Q1-2010Q3 \\
\hline Korea & Nationwide house price index & No & Kookmin Bank & 1986Q1-2010Q4 \\
\hline Netherlands & Existing dwellings & No & $\begin{array}{l}\text { Nederlandsche } \\
\text { Bank }\end{array}$ & 1970Q1-2010Q4 \\
\hline New Zealand & $\begin{array}{l}\text { Quotable value index for dwellings } \\
\text { (new and existing) }\end{array}$ & No & Reserve Bank & 1970Q1-2010Q4 \\
\hline Norway & Nationwide index for dwellings & Yes & $\begin{array}{l}\text { Statistics Norway, } \\
\text { Table } 03860\end{array}$ & 1970Q1-2010Q4 \\
\hline Spain & $\begin{array}{l}\text { Precio medio del } \mathrm{m} 2 \text { de la vivienda, } \\
\text { mas de un año de antiguedad }\end{array}$ & No & Banco de Espana & 1971Q1-2010Q4 \\
\hline Sweden & One and two dwelling buildings & No & Statistics Sweden & 1970Q1-2010Q4 \\
\hline Switzerland & Single-family home & No & $\begin{array}{l}\text { Swiss National } \\
\text { Bank }\end{array}$ & 1970Q1-2010Q4 \\
\hline $\begin{array}{l}\text { United } \\
\text { Kingdom }\end{array}$ & Mix-adjusted house price index & No & ODPM & 1970Q1-2010Q4 \\
\hline United States & $\begin{array}{l}\text { Nation-wide single family house } \\
\text { price index }\end{array}$ & No & FHFA & 1975Q1-2010Q4 \\
\hline
\end{tabular}


ECO/WKP(2011)51

\section{Appendix 2. Data sources and definitions of the variables}

\begin{tabular}{ll}
\hline Variable & Description \\
\hline
\end{tabular}

Nominal house price

Real house price

Real house price gap

Real house price (percentage change)

Peak

Trough

Number of peaks in other OECD countries

Long-term interest rate $(\log )$

Long-term interest rate (percentage change)

Inflation rate $(\%)$

Residential investment (as \% of GDP)

Unemployment gap (\%)
See Appendix 1 for the details.

Nominal house price deflated by the private final consumption expenditure deflator.

Defined as the logarithm of the real house price minus the time-trend.

Defined as $\frac{\mathrm{p}_{\mathrm{t}}-\mathrm{p}_{\mathrm{t}-1}}{\mathrm{p}_{\mathrm{t}-1}} * 100 \%$, where $\mathrm{P}_{\mathrm{t}}$ is the real house price.

Dummy variable that takes a value of 1 if a local maximum with respect to six leads and lags in real house prices is reached and if the cumulative price increase prior to and the cumulative price decrease after the local maximum is at least $15 \%$ and $7.5 \%$, respectively. See Section 3 for more details.

Dummy variable that takes a value of 1 if a local minimum with respect to six leads and lags in real house prices is reached and if the cumulative price decrease prior to and the cumulative price increase after the local maximum is at least $7.5 \%$ and $15 \%$, respectively. See Section 3 for more details.

Total number of peaks in other OECD countries than the reference country in the same quarter.

The logarithm of the long-term interest rate, available from the OECD Economic Outlook 89 database.

Defined as $\frac{r_{t}-r_{t-1}}{r_{t-1}} * 100 \%$, where $r_{t}$ is the long-term interest rate.

Annualised inflation rate in $\%$ based on private final consumption expenditure deflator, available from the OECD Economic Outlook 89 database.

Gross fixed capital formation in the housing sector, available from the OECD Economic Outlook 89 database.

Defined as unemployment rate minus NAIRU (=unemployment rate with non-accelerating inflation rate) in $\%$ of labour force, available from the OECD Economic Outlook 89 database. 
Appendix figure A.1: In-sample predictions of peaks and troughs

Australia

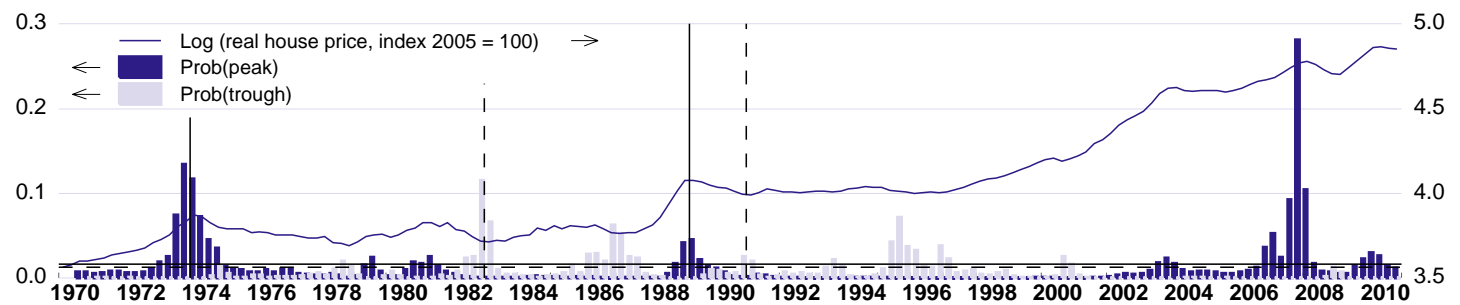

Belgium

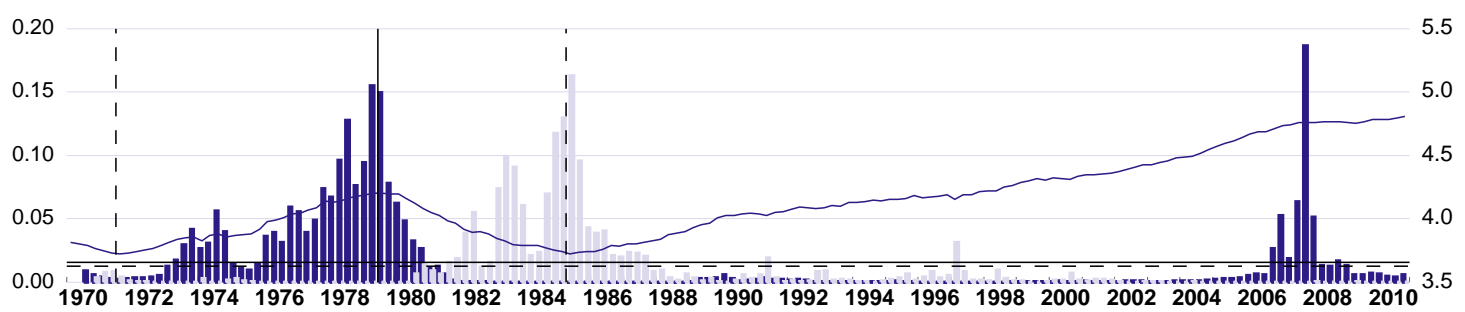

Canada

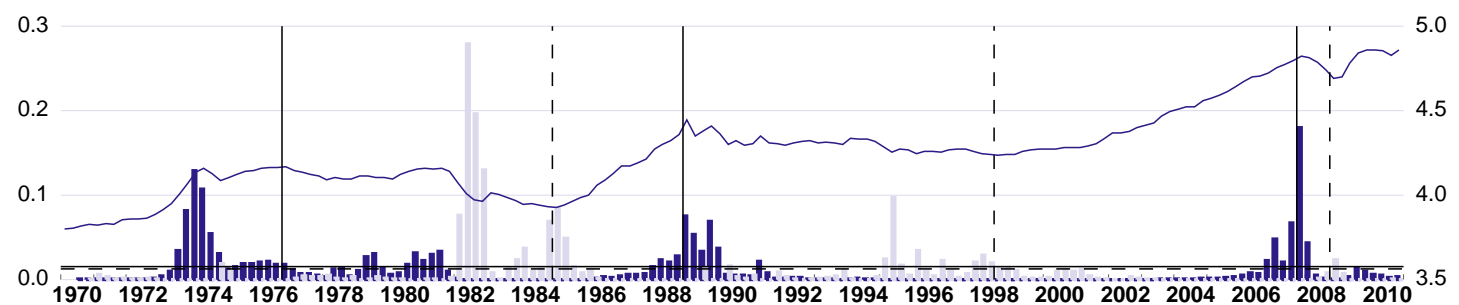

Denmark

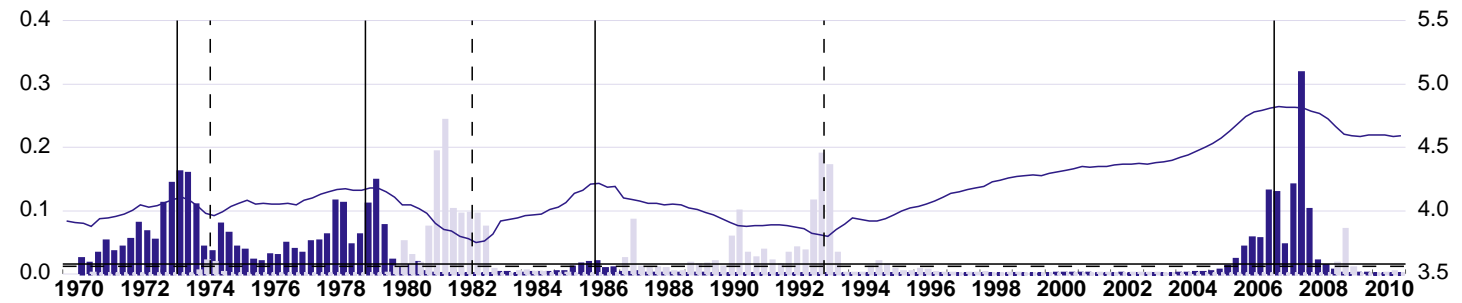

Finland

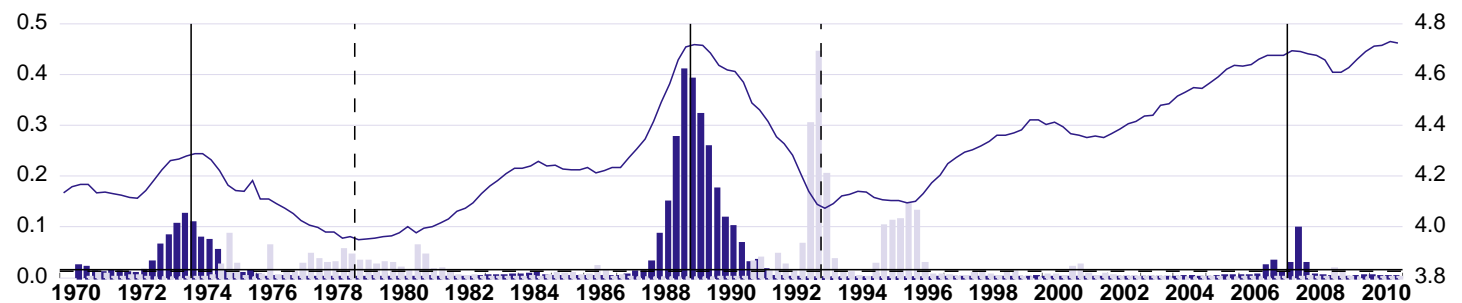

Note: Vertical solid and dashed lines indicate called peaks and troughs, respectively. Horizontal solid and dashed lines represent the cut-off level used for the predictions of peaks and troughs, respectively.

Source: Authors' computations based on the models in Table 1. 
Appendix Figure A.1, cont.

France

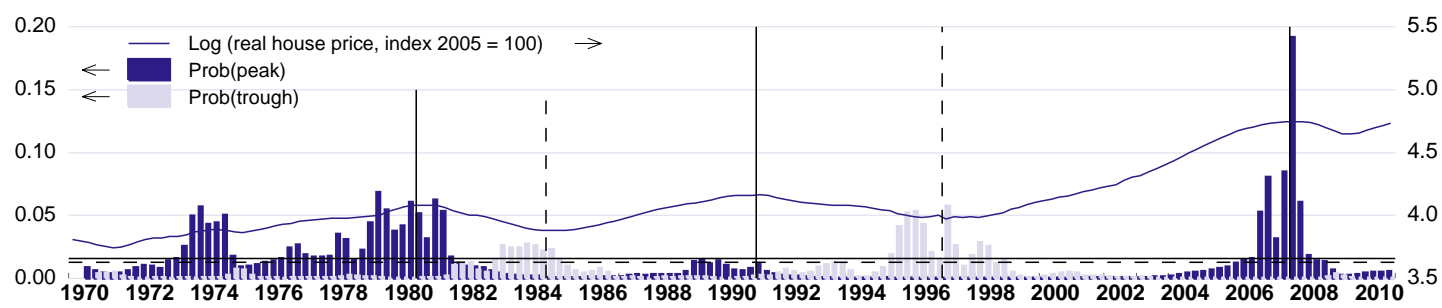

Germany

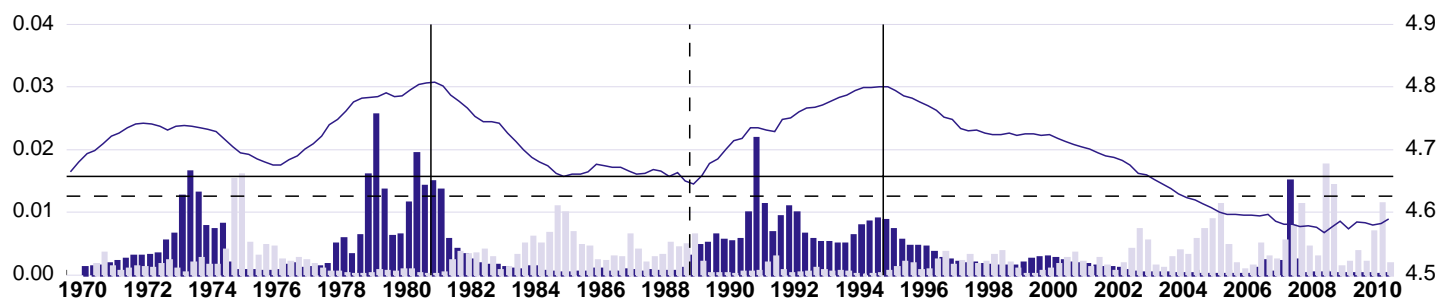

Greece

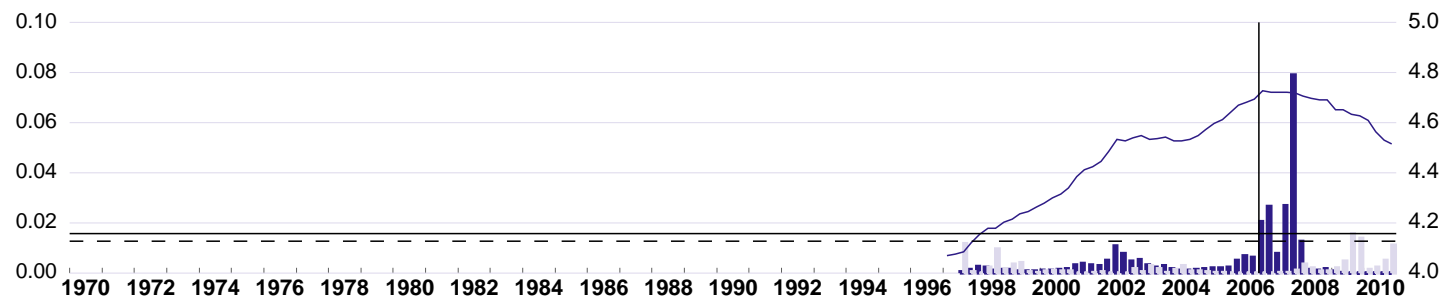

Italy

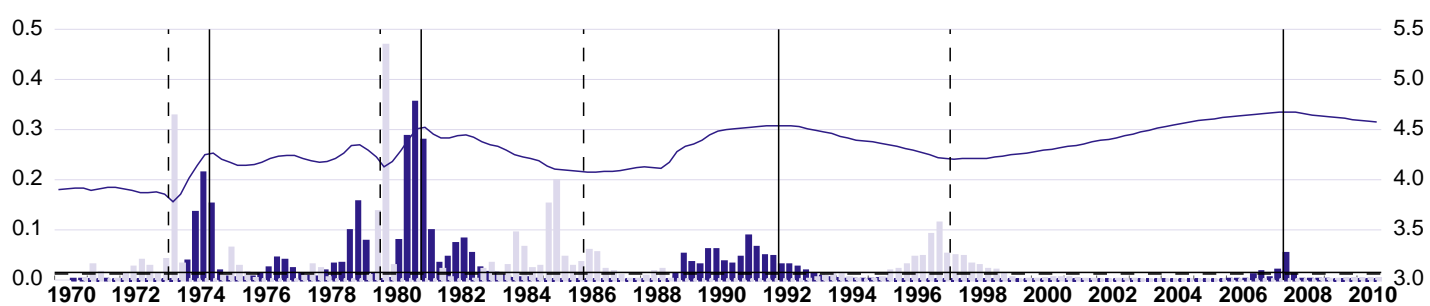

Ireland

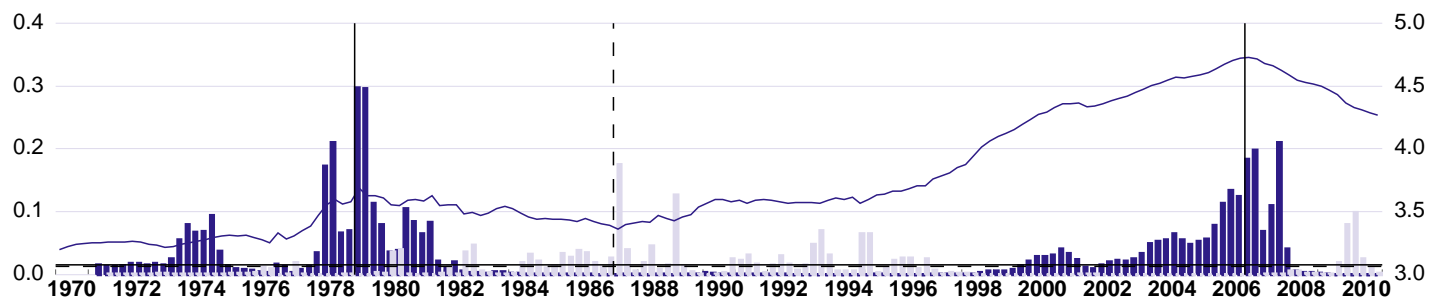

Note: Vertical solid and dashed lines indicate called peaks and troughs, respectively. Horizontal solid and dashed lines represent the cut-off level used for the predictions of peaks and troughs, respectively.

Source: Authors' computations based on the models in Table 1. 
Appendix figure A.1, cont.

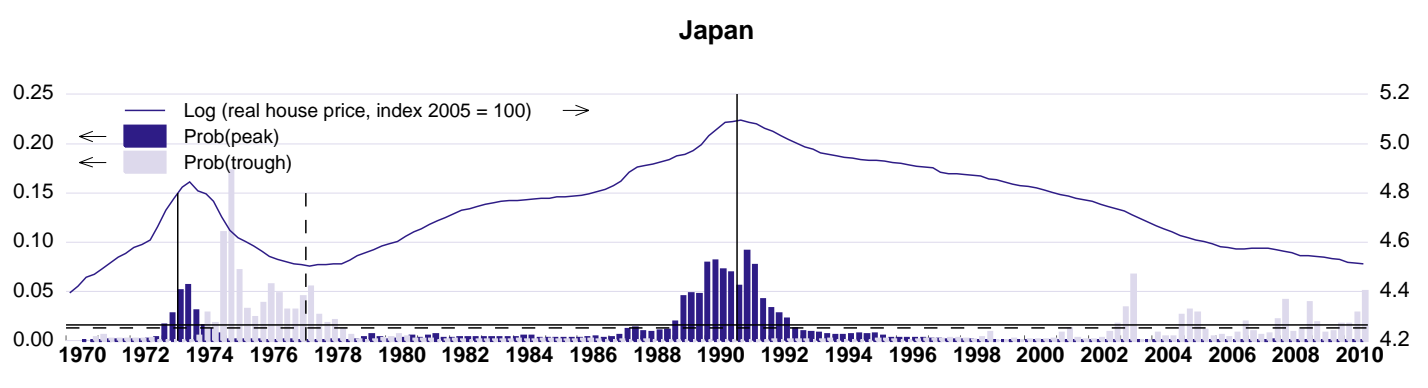

Korea

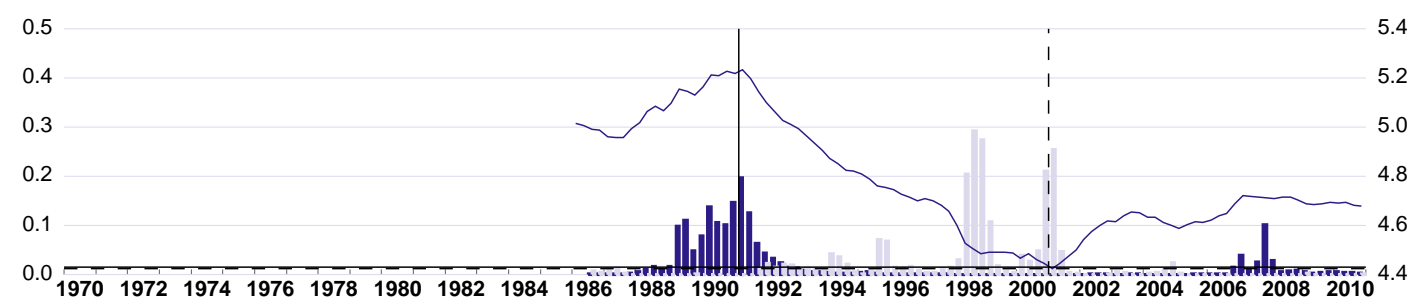

Netherlands

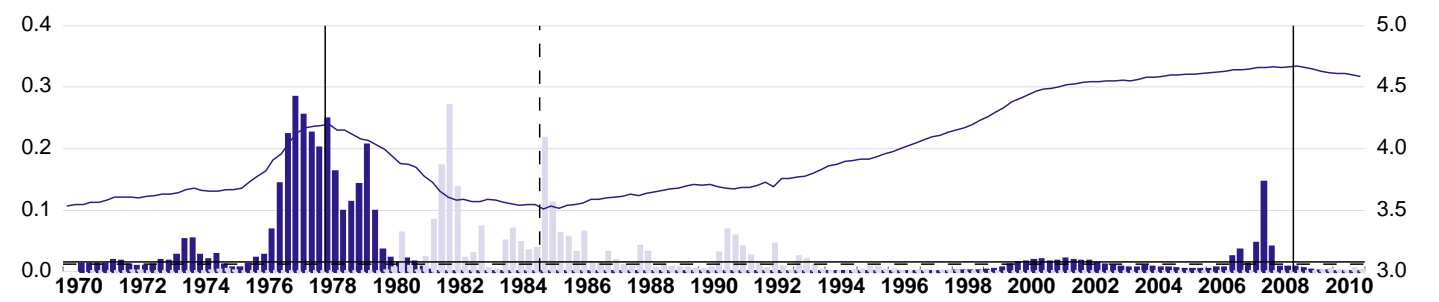

New Zealand

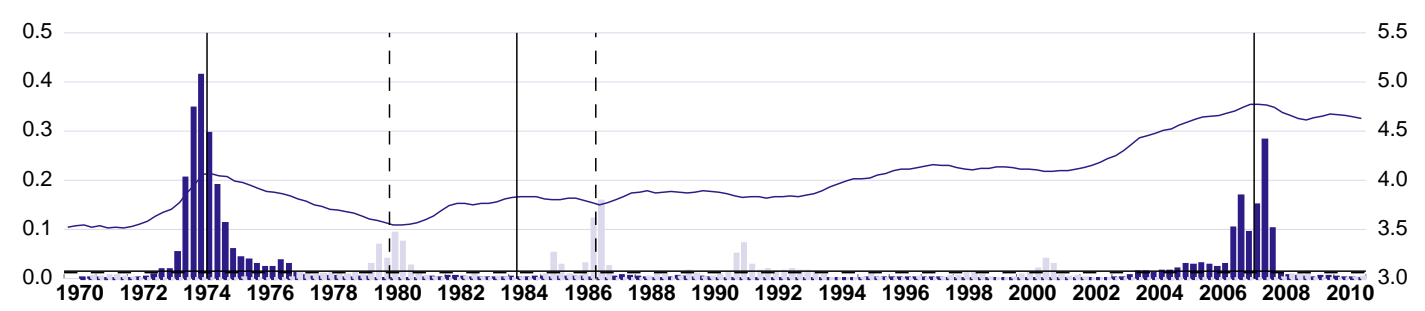

Norway

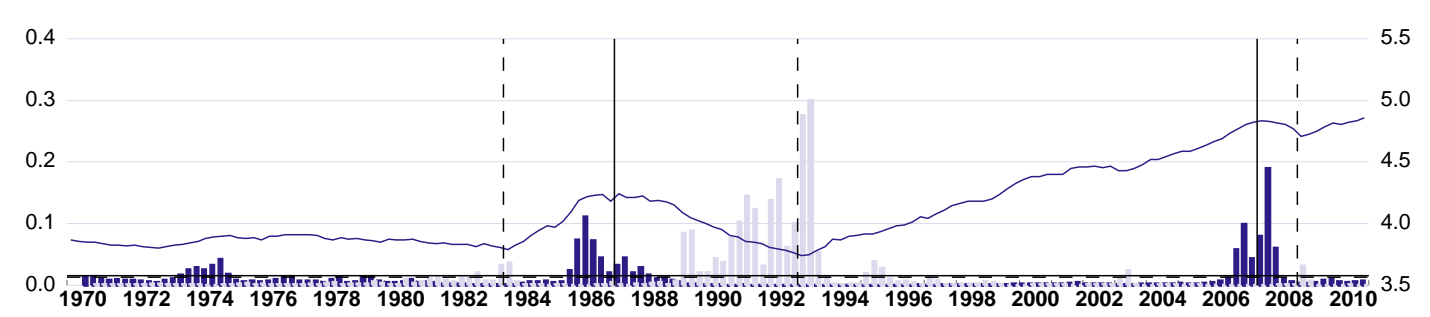

Note: Vertical solid and dashed lines indicate called peaks and troughs, respectively. Horizontal solid and dashed lines represent the cut-off level used for the predictions of peaks and troughs, respectively.

Source: Authors' computations based on the models in Table 1. 
Appendix Figure A.1, cont.

Spain

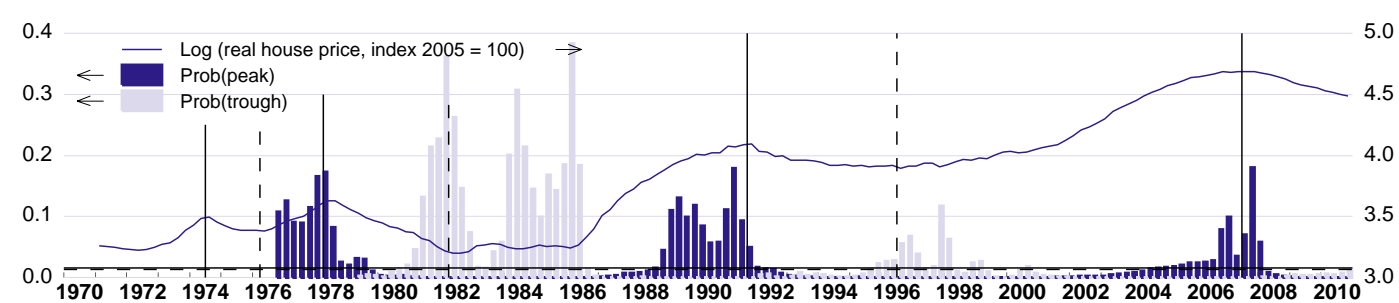

Sweden

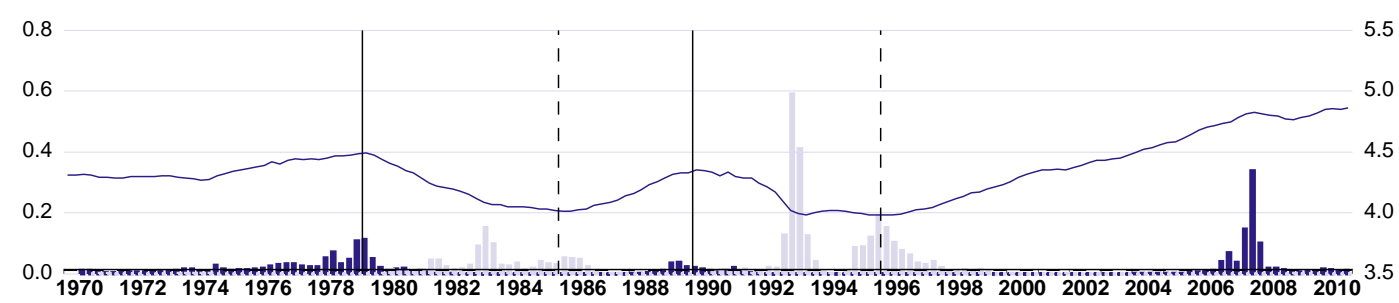

Switzerland

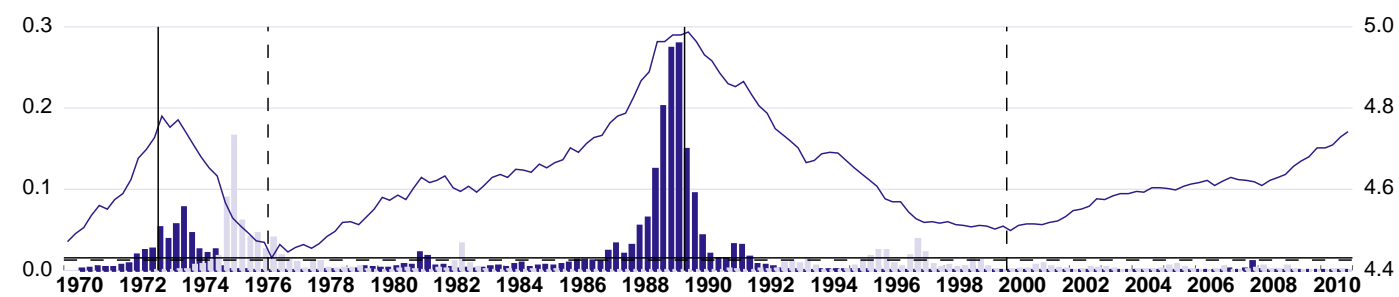

United Kingdom

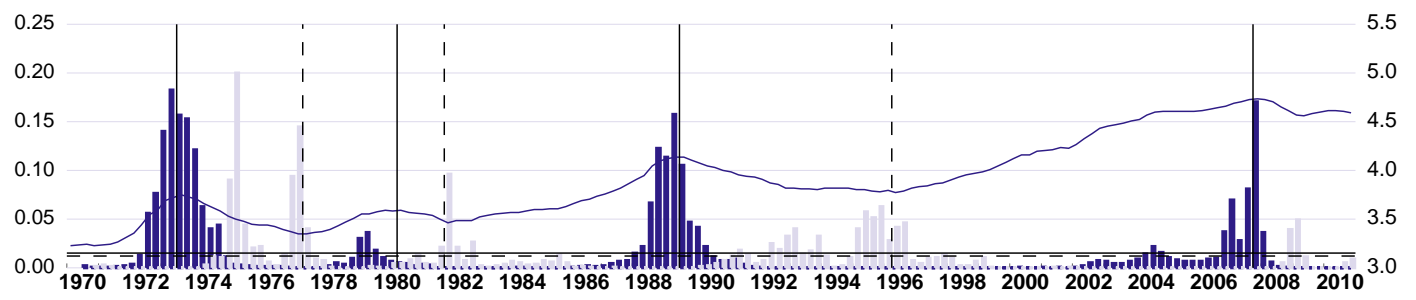

United States

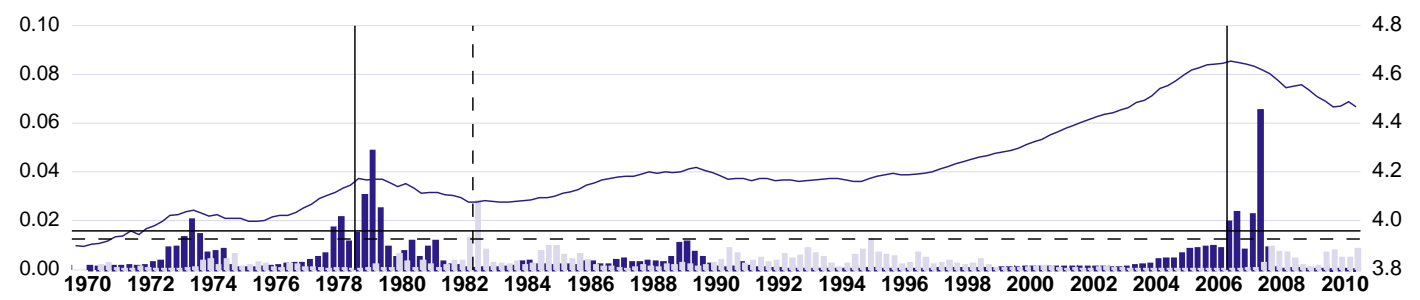

Note: Vertical solid and dashed lines indicate called peaks and troughs, respectively. Horizontal solid and dashed lines represent the cut-off level used for the predictions of peaks and troughs, respectively.

Source: Authors' computations based on the models in Table 1. 
Appendix Figure A.2: Out-of-sample predictions of peaks, 2006-10

\section{Australia}

0.30

0.25

0.20

0.15

0.10

0.05

0.00

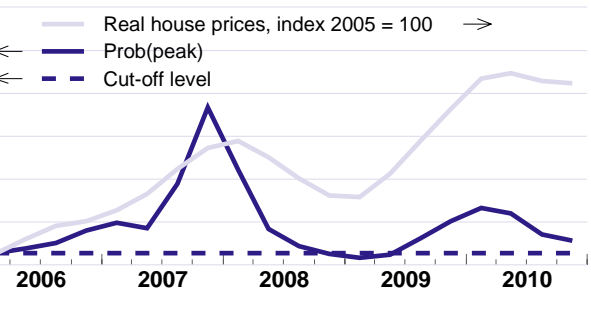

Canada

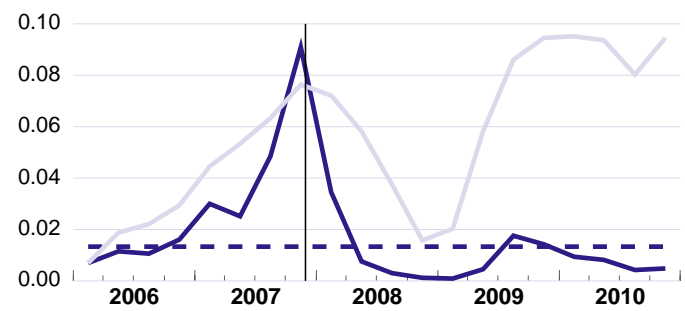

Finland

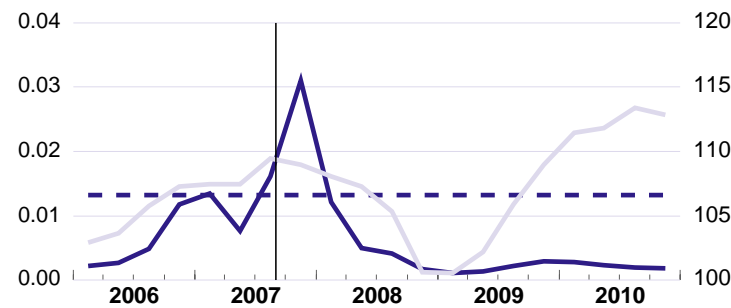

Germany

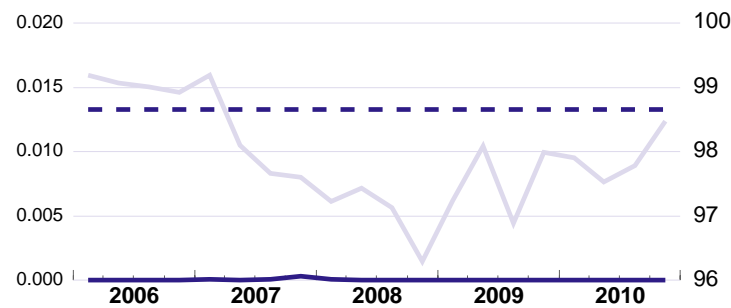

Italy

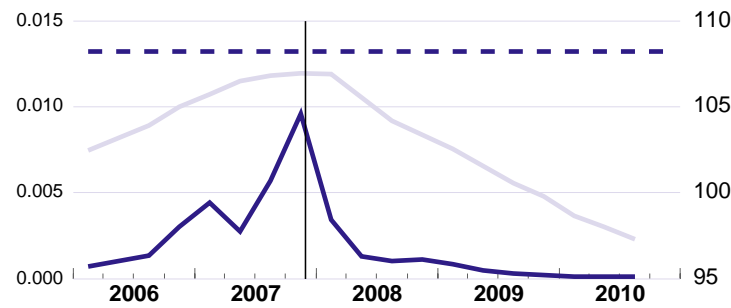

Belgium

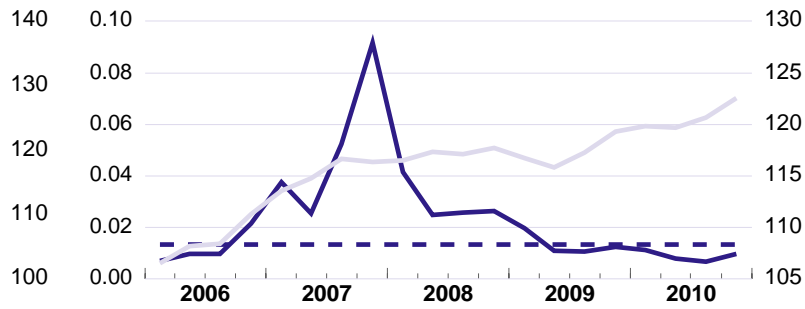

Denmark

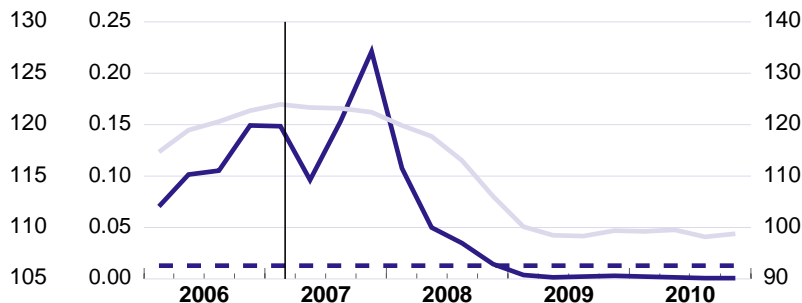

France

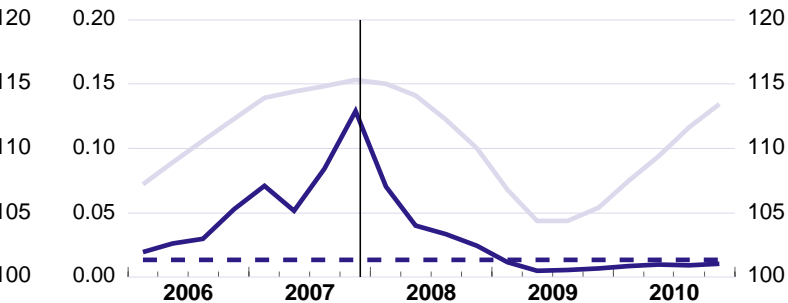

Greece

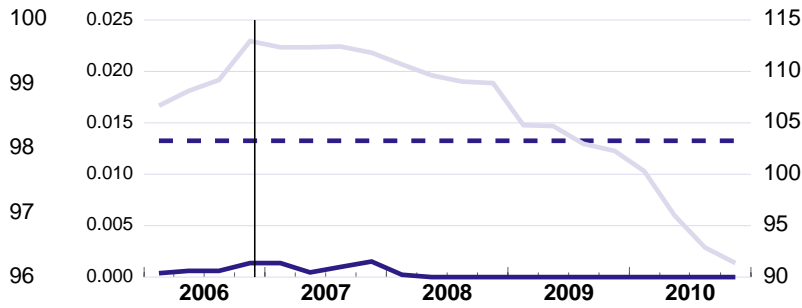

Ireland

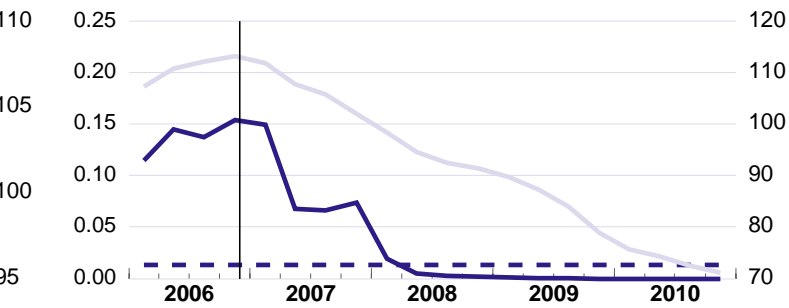

Note: Vertical lines indicate called peaks.

Source: Authors' computations based on the model for peaks in Table 2. 
Appendix Figure A.2, cont.

Japan

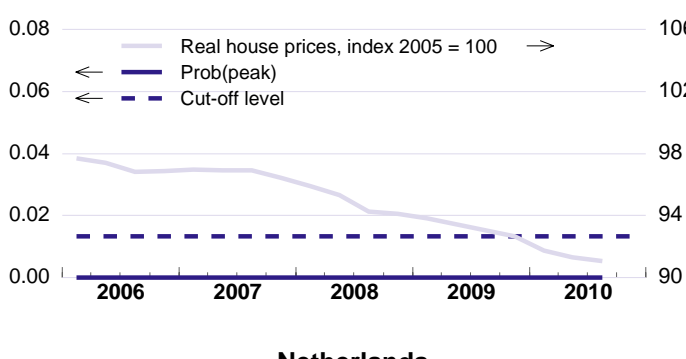

Netherlands

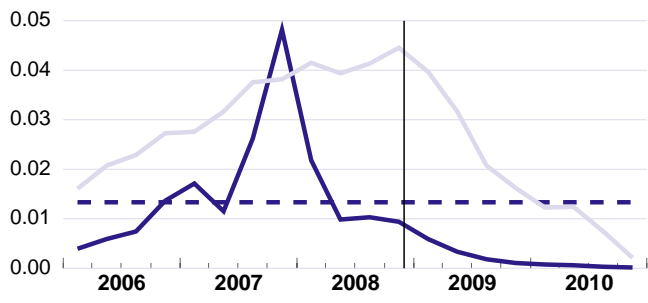

Norway

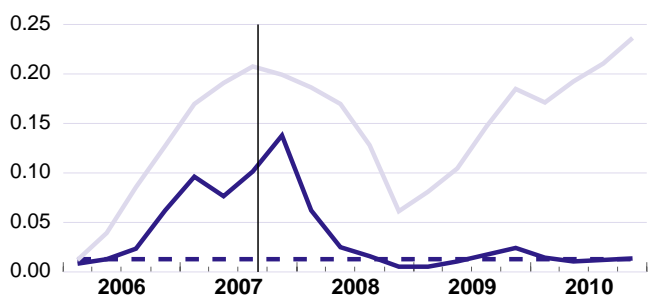

Sweden

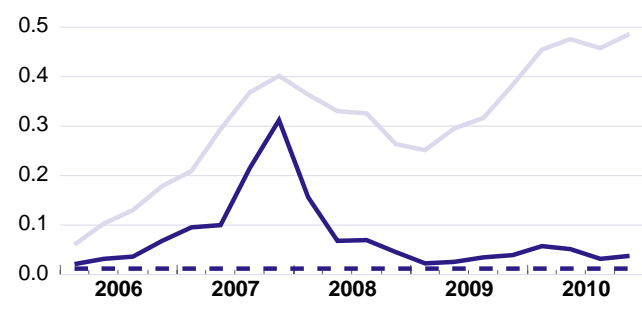

United Kingdom

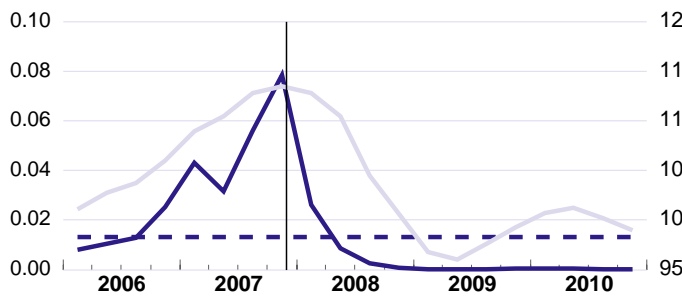

Korea

\begin{tabular}{cc}
106 & 0.10 \\
& \\
102 & 0.08 \\
& 0.06 \\
98 & 0.04 \\
& 0.04 \\
94 & 0.02 \\
90 & 0.00 \\
\hline
\end{tabular}

$108 \quad 0.25$

$106 \quad 0.20$

$104 \quad 0.15$

$102 \quad 0.10$

100

0.00

$=$

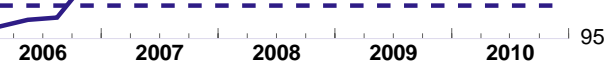

New Zealand

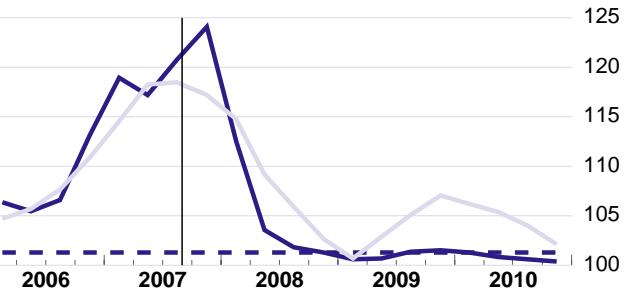

Spain

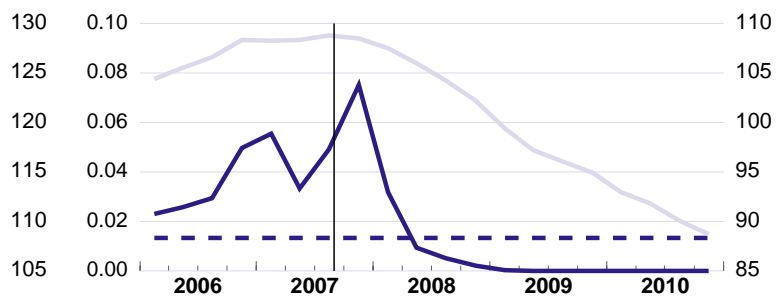

Switzerland

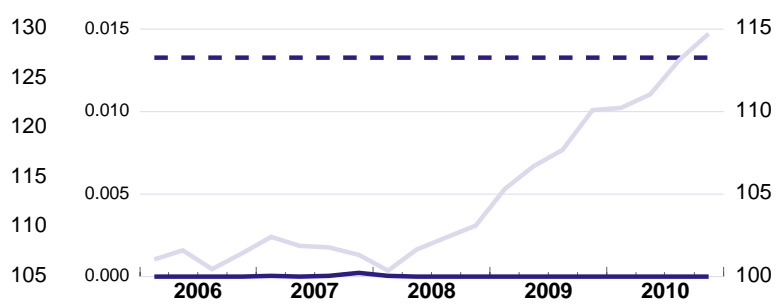

United States

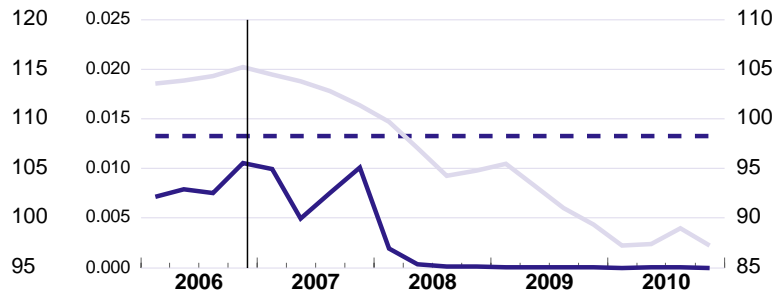

Note: Vertical lines indicate called peaks.

Source: Authors' computations based on the model for peaks in Table 2. 
Appendix Figure A.3: Out-of-sample predictions of troughs, 2006-10

Australia
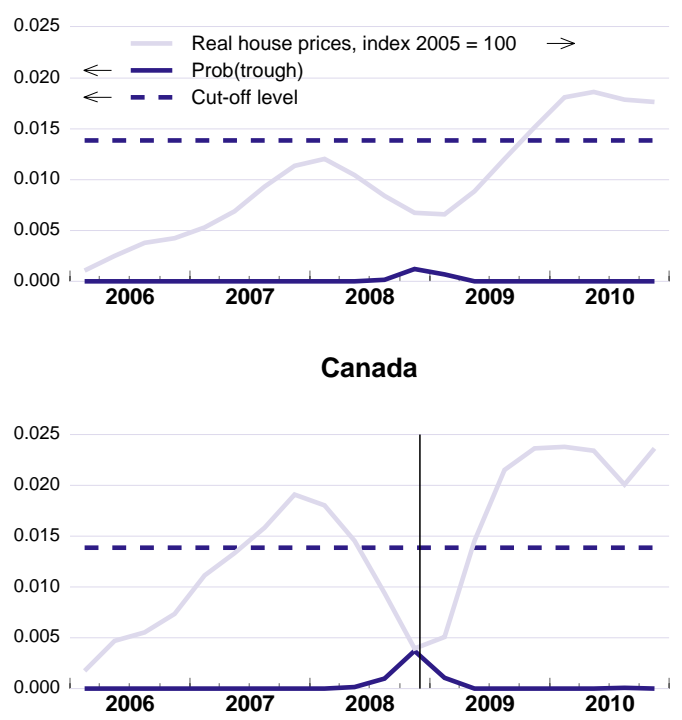

Finland

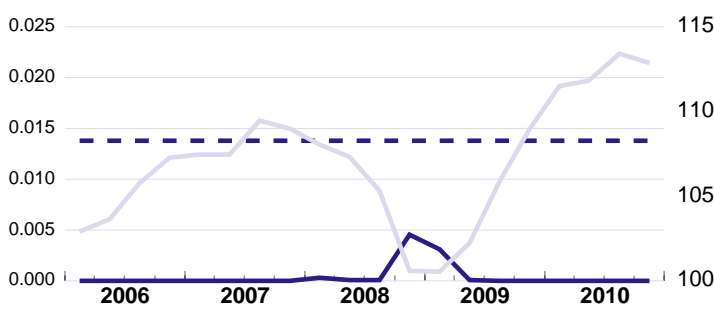

Germany

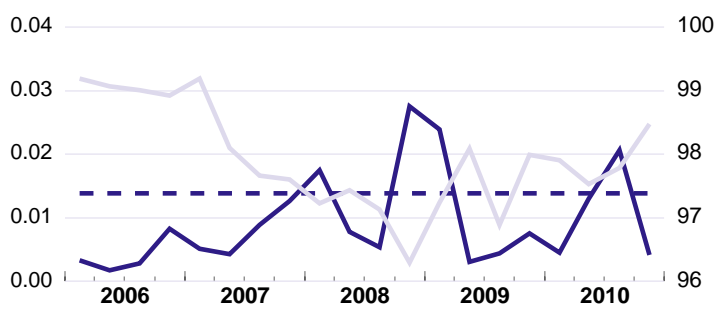

Italy

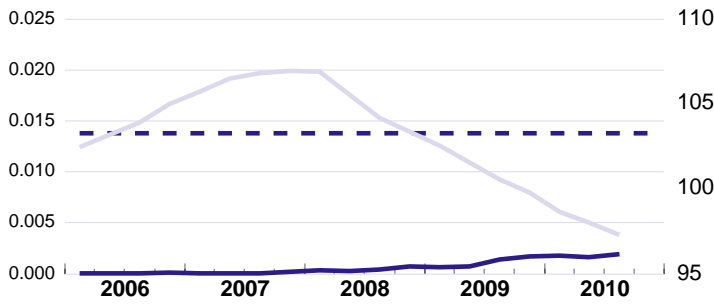

Belgium
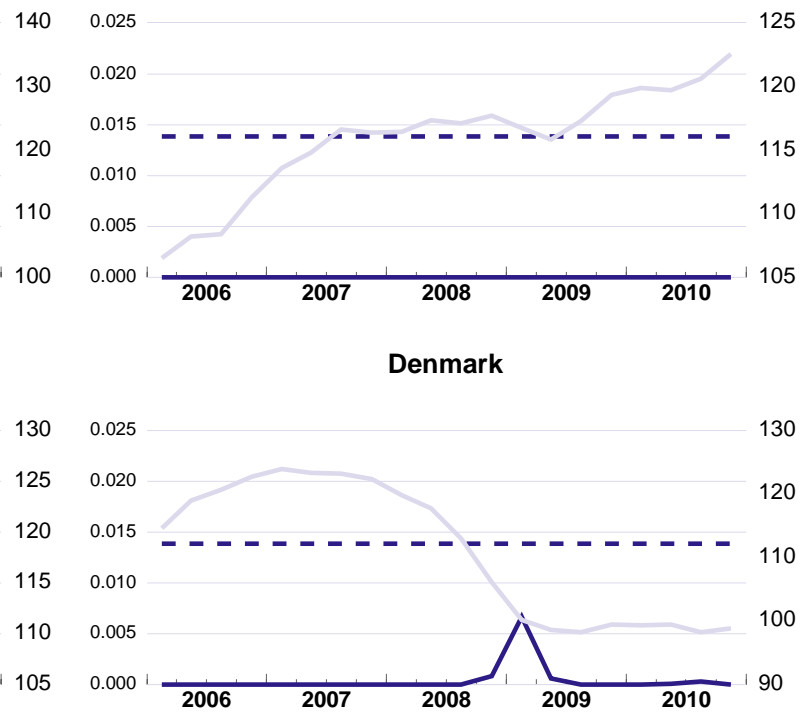

France

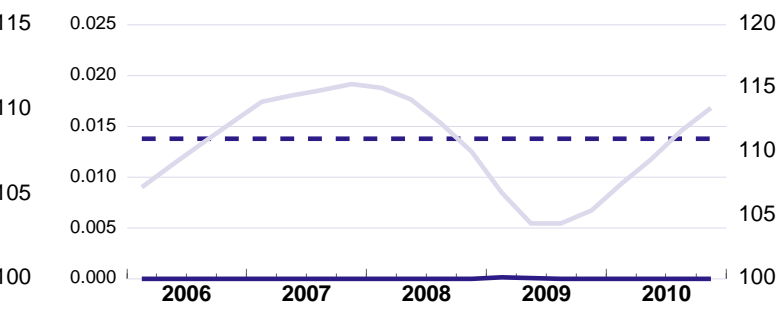

Greece

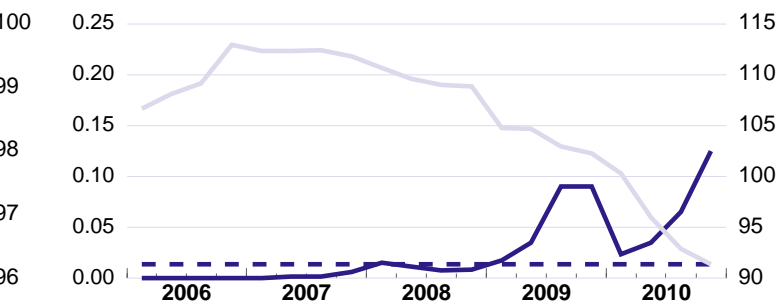

Ireland

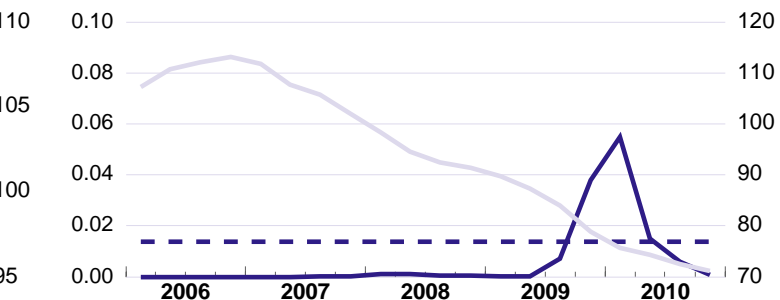

Note: Vertical lines indicate called troughs.

Source: Authors' computations based on the model for troughs in Table 2. 
ECO/WKP(2011)51

Appendix Figure A.3, cont.

Japan

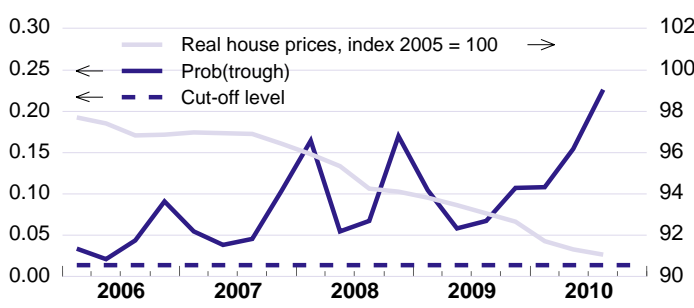

Netherlands
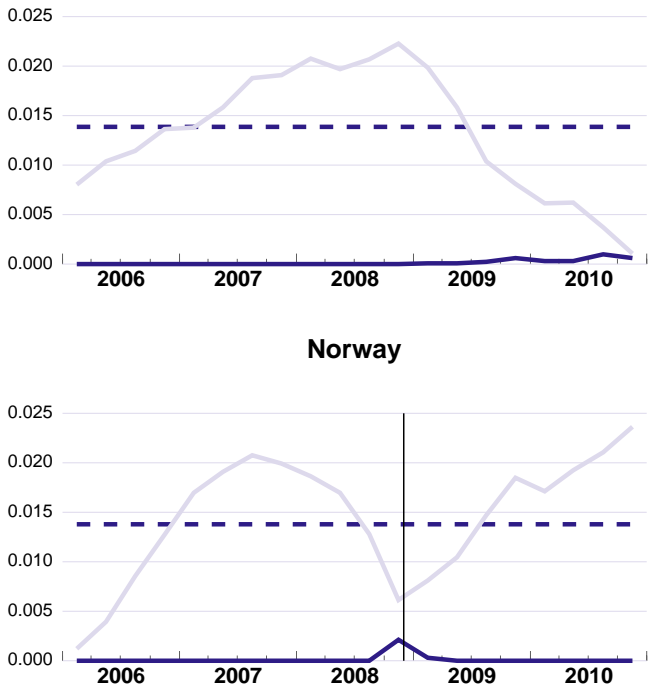

Sweden

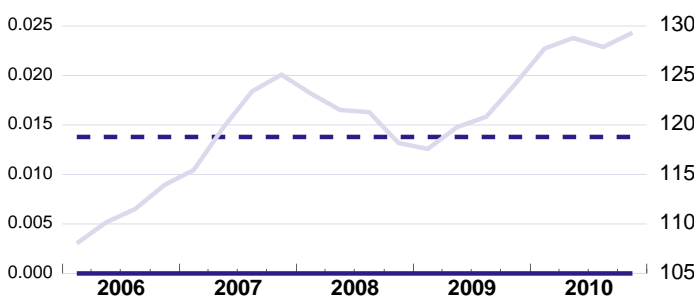

United Kingdom

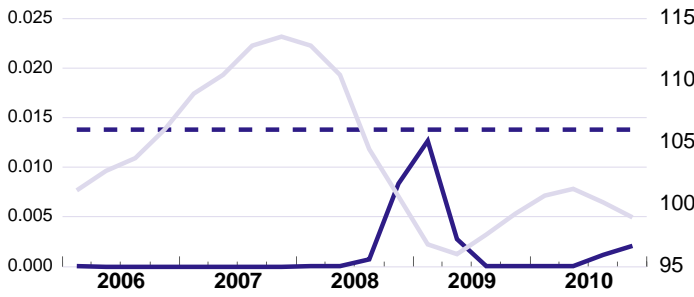

Korea

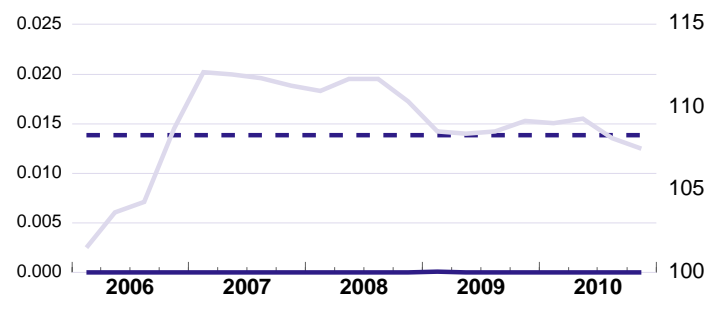

New Zealand
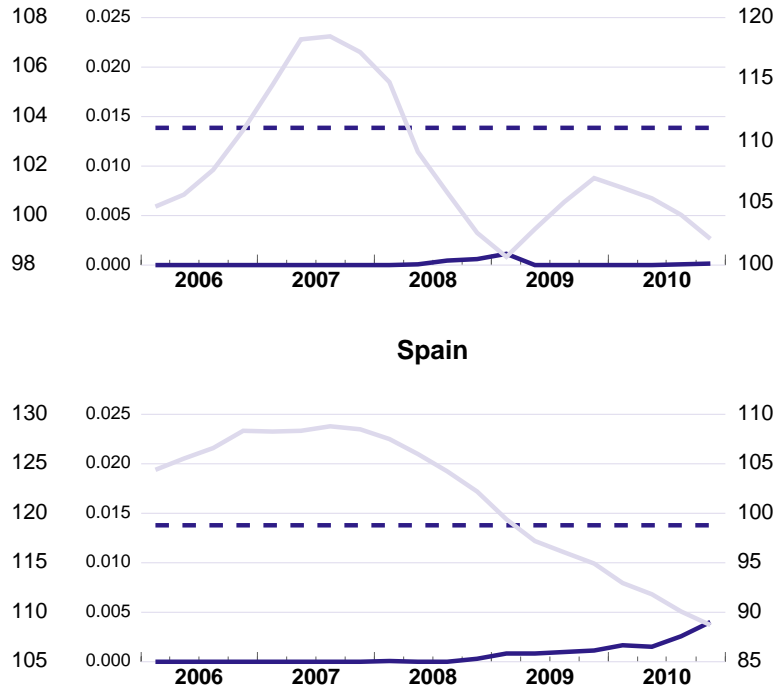

Switzerland

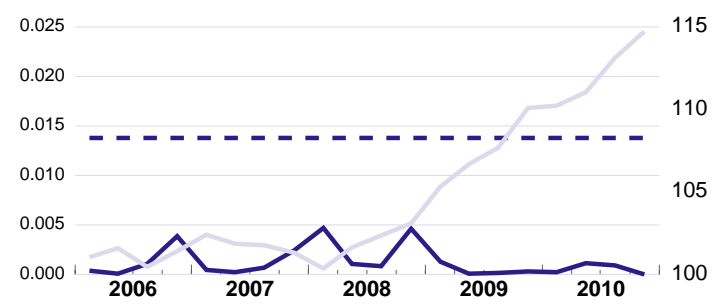

United States

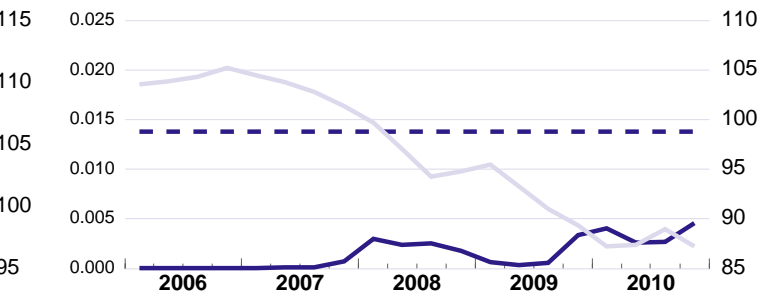

Note: Vertical lines indicate called troughs.

Source: Authors' computations based on the model for troughs in Table 2. 
ECO/WKP(2011)51

\section{WORKING PAPERS}

The full series of Economics Department Working Papers can be consulted at www.oecd.org/eco/workingpapers/

881. Public sector spending efficiency in Estonia: healthcare and local government (July 2011) by Zuzana Smidova

880. How to move Product Market Regulation in New Zealand back towards the frontier (July 2011) by Paul Conway

879. Financial sector reform in India: time for a second wave? (July 2011) by Richard Herd, Vincent Koen, Ila Paitnak and Ajay Shah

878. Policies to rebalance housing markets in New Zealand (July 2011) by Calista Cheung

877. The sharing of macroeconomic risk: Who loses (and gains) from macroeconomic shocks (July 2011) Rudiger Ahrend, Jens Arnold and Charlotte Moeser

876. Estonia: making the most of globalisation (June 2011) Robert Price and Andreas Wörgötter

875. The effects of downturns on labour force participation: evidence and causes (June 2011) Romain Duval, Mehmet Eris and Davide Furceri

874 A dynamic factor model for world trade growth (June 2011) Stéphanie Guichard and Elena Rusticelli

873. Towards a better understanding of the informal economy (May 2011) Dan Andrews, Aida Caldera Sánchez and Åsa Johansson

872. Tax competition between sub-central governments (May 2011) Hansjörg Blöchliger and José-Maria Pinero-Campos

871. The growth effects of current account reversals: the role of macroeconomic policies (May 2011) Luiz de Mello, Pier Carlo Padoan and Linda Rousová

870. Les politiques du logement en France (May 2011) Bénédicte Rolland

869. How important is wealth for explaining household consumption over the recent crisis? An empirical study for the United States, Japan and the euro area

(May 2011) Clovis Kerdrain

868. Adjusting fiscal balances for asset price cycles (May 2011) Robert Price and Thai-Thanh Dang

867. Improving the functioning of the housing market in the United Kingdom (May 2011) Christophe André

866. An analysis of demand for foreign exchange reserves 
(May 2011) Peter Vujanovic

865. Episodes of large capital inflows and the likelihood of banking and currency crises and sudden stops

(May 2011) Davide Furceri, Stephanie Guichard and Elena Rusticelli

864. The effect of episodes of large capital inflows on domestic credit

(May 2011) Davide Furceri, Stephanie Guichard and Elena Rusticelli

863. Medium-term determinants of international investment positions: the role of structural policies (May 2011) Davide Furceri, Stephanie Guichard and Elena Rusticelli

862. French social housing in an international context

(May 2011) Kathleen Scanlon and Christine Whitehead

861. Making the French housing market work better

(May 2011) by Hervé Boulhol

860. Surveillance by international institutions: lessons from the global financial and economic crisis (April 2011) by Kumiharu Shigehara and Paul Atkinson

859. France's environmental policies: internalising global and local externalities (April 2011) by Balázs Égert

858. Bringing French public debt down: the options for fiscal consolidation (April 2011) by Balázs Égert

857. Policy frameworks in the post-crisis environment (April 2011) by Nigel Pain and Oliver Röhn

856. Global imbalances, exchange rate pegs and capital flows: a closer look (April 2011) by Paul van den Noord

855 Interest rate pass-through during the global financial crisis: the case of Sweden (April 2011) by Niels-Jakob Harbo Hansen and Peter Welz

854 What drives inflation in the major OECD Economies

(April 2011) by Diego Moccero, Shingo Watanabe and Boris Cournède

853 Mitigation potential of removing fossil fuel subsidies: A general equilibrium assessment (April 2011) by J.M. Burniaux and J. Chateau

852 Enhancing labour utilisation in a socially inclusive society in Australia (April 2011) by Vassiliki Koutsogeorgopoulou

851 Meeting infrastructure needs in Australia (March 2011) by Claude Giorno

850 Restoring fiscal sustainability in Spain

(March 2011) by Pierre Beynet, Andrés Fuentes, Robert Gillingham and Robert Hagemann 